\title{
IMÁGENES (D)E HISTORIA. UNA MIRADA SOBRE LOS FRAGMENTOS VISUALES DE LA ÚLTIMA DICTADURA EN LA ARGENTINA
}

\author{
ROBERTO PITTALUGA (UBA/IESH-UNLPam) \\ Instituto de Estudios Sociohistóricos \\ Facultad de Ciencias Humanas \\ Universidad Nacional de La Pampa \\ roberto.pittaluga@gmail.com
}

\section{Resumen:}

A partir de un conjunto diverso de imágenes (primeras planas de periódicos, fotografías y avisos gráficos estatales), el autor ensaya distintas formas de mirar y leer las huellas que ha dejado la última dictadura en la Argentina, en relación a una nueva configuración de los lazos sociales y sus correspondientes figuras de subjetividad. El trabajo sobre esos fragmentos no pretende reducir lo visual a lo legible, ni tampoco anular las tensiones, ambigüedades y malestares que provoca mirar esas imágenes.

\section{Palabras Claves:}

Imágenes - Argentina - Golpe de Estado - Dictadura

\begin{abstract}
From a diverse set of images (front pages of newspapers, photographs and state propaganda), the author tries different ways of seeing and reading the traces left by the last dictatorship in Argentina, in relation to a new configuration of social ties and their corresponding figures of subjectivity. The work on these fragments is not intended to reduce its visuality to legibility, nor to remove tensions, ambiguities and disconfort that results from looking at those images.
\end{abstract}

Key words:

Images - Argentina - Coup d'Etat - Dictatorship 


\title{
IMÁGENES (D)E HISTORIA. UNA MIRADA SOBRE LOS FRAGMENTOS VISUALES DE LA ÚLTIMA DICTADURA EN LA ARGENTINA
}

\author{
ROBERTO PITTALUGA (UBA/IESH-UNLPam) \\ roberto.pittaluga@gmail.com
}

Madrugada del 24 de marzo de 1976. Héctor "Puchi" Vázquez esperaba frente a la Casa Rosada junto a otros reporteros gráficos y periodistas que el golpe, que se sabía estaba por ocurrir, se consumara. Golpe anunciado, ni siquiera era un pronóstico, era una certeza. Se lo esperaba en minutos. ${ }^{1}$

Pero había distintas esperas de lo que sucedería. Estaban quienes lo anhelaban -al golpeansiosos porque lo creían -y tendrán razón- inflexión, expediente necesario que los devolviera al país normal de la subordinación de los subalternos (lo dijo Videla: sería "un escarmiento histórico"²). Otros lo aguardaban tan sólo con la resignada expectativa -y en esto consistió la ilusión- de que la represión legal eliminara, o al menos moderara significativamente, la amplísima y brutal violencia paralegal de la Triple A y otros comandos similares, que en algo más de dos años habían asesinado a más de 1500 activistas políticos y sociales; ${ }^{3}$ era ésta la espera de una repetición basada en saberes de anteriores dictaduras que la nueva vendría a trastocar gravemente.

También estaban quienes lo aguardaban como una circunstancia clarificadora, capaz de iluminar lo que -decían- bajo el régimen constitucional se presentaba opaco: al desprenderse de las

\footnotetext{
1 "La decisión de tomar el poder por las Fuerzas Armadas no toma de sorpresa a los observadores políticos", se afirma en Diario Clarín, Buenos Aires, del 24 de marzo de 1976, p. 3. Este diario realizó dos ediciones ese 24 de marzo; la única diferencia entre las primeras planas de ambas ediciones es que la noticia "Calabró entregó la gobernación" de la primera edición es reemplazada por "Comunicados de la Junta Militar".

2 "El objetivo del proceso de Reorganización Nacional es realizar un escarmiento histórico (...) En la Argentina deberán morir todas las personas que sean necesarias para terminar con la subversión”, Gral. Jorge Rafael Videla, "Declaraciones en Washington el 8/9/1977", en Diario Crónica el 9 de septiembre de 1977. El propio Videla lo había dicho casi del mismo modo el 25 de octubre de 1975: “...si es preciso, en la Argentina deberán morir todas las personas necesarias para lograr la seguridad del país” (Cf. Diario Clarín, Diario La Nación y otros, 26 de octubre de 1975).

${ }^{3}$ Para el accionar y las cifras de asesinatos de la Triple A, cf. Franco, Marina, Un enemigo para la nación. Orden interno, violencia y "subversión", Buenos Aires, Fondo de Cultura Económica, 2012.
} 
mediaciones, quedaría al descubierto la que creían era la verdadera cara del poder, su ultima ratio (sólo que no estimaron ni su fuerza real ni su capacidad para imponer condiciones nuevas). ${ }^{4}$

Y por supuesto, estaban quienes guardaban la esperanza cada vez más imposible de que no se produjera, que ese acontecimiento anunciado no tuviera lugar, porque suponían, con particular agudeza, que significaría un terror impensable hasta entonces; eran éstos los que esperaban con un miedo a todas luces justificado.

Probablemente entre estos últimos se encontraba Héctor "Puchi” Vázquez, a juzgar por su testimonio de $2005 .{ }^{5}$ De todos modos, ese día estaba frente a la casa de gobierno porque en eso consistía su trabajo, en intentar fotografiar algo que diera cuenta del momento, de ese instante que nombra el acontecimiento como "golpe".

¿Cómo se muestra un golpe? ¿Qué imagen o imágenes lo representan? ¿Cuáles tienen ese particular valor referencial? ¿Qué enunciados las acompañan? Para algunos medios, como los periódicos Clarín y La Nación, las imágenes que captaban el sentido de la situación fueron varias desde ese 24 de marzo (y lo mejor es verlas relacionadas): aquella del helicóptero llevándose a la presidenta destituida, "Isabel" Perón, de la Casa Rosada; la de una Plaza de Mayo "casi vacía", con apenas una treintena de seguidores de la presidenta; distintas versiones de la asunción de la junta militar; fotografías de calles ocupadas por fuerzas militares (carros, tanques, soldados). ${ }^{7} \mathrm{La}$ prensa masiva construye el momento del desplazamiento del gobierno peronista como "desenlace" natural y previsible de una "prolongada crisis política", como "culminación de un proceso" caracterizado por la impotencia del gobierno peronista frente a "fuerzas centrífugas desencadenadas" que ponían en "peligro cierto (...) la integridad nacional", y que finalmente encontraron su contrapeso en el abandono de la "actitud de prescindencia" de las Fuerzas Armadas y su asunción del poder.

Naturalizar la situación, presentar el golpe de Estado como un resultado necesario, "la decisión" golpista como "ineludible". Para abonar esta lectura del momento, Clarin apostaba a mostrar el "vacío de poder" -que según los dichos del sentido común sobre la política se asocia a la ilegitimidad, al caos o a la ineptitud- por medio de "una plaza vacía": en la primera plana del 24 de marzo de 1976, junto a la pequeña fotografía del helicóptero despegando de la terraza de la

\footnotetext{
4 Cf. los documentos y publicacion1es de Montoneros y PRT-ERP en los meses previos al golpe y cómo lo evaluaron una vez acaecido, sobre todo en los inmediatos meses siguientes. Tales documentos pueden consultarse en los sitios www.ruinasdigitales.com.ar y www.eltopoblindado.com.ar. De todos modos, es importante señalar que estas mismas organizaciones o, mejor dicho, algunos de sus miembros, a pesar de la lógica militarista prevaleciente intuyeron parcialmente la gravedad de una nueva dictadura, incluso bastante antes del golpe de 1976; cf. Pittaluga, Roberto, "La memoria según Trelew" en Sociobistórica. Cuadernos del CISH, no 19/20, UNLP, La Plata, 2008, pp. 81111.

5 Cf. Testimonio de Héctor "Puchi” Vázquez, Archivo Oral de Memoria Abierta, 2005; entrevistador: Pablo Palomino; cámara: Marcelo Rest.

6 “... el fotógrafo, a diferencia del redactor, se tiene que meter en el medio del quilombo... y encima va disfrazado, con cámara...”, comenta en su testimonio el propio Vázquez; op. cit.

${ }^{7}$ Fotografías con alguno de estos motivos son las seleccionadas para las primeras planas de los principales periódicos de la época (Clarín, La Nación, La Razón, Crónica) los días 24 y el 25 de marzo. No es el propósito de este trabajo analizar los modos por los cuales la prensa escrita expuso el inicio de la dictadura, pero sí señalar algunos de sus aspectos en tanto su análisis contribuye a la comprensión de los marcos interpretativos que definen los modos de representabilidad de la situación.

8 "La culminación de un proceso", Clarín, 24 de marzo de 1976, p. 3, 1 ed. Que el golpe no tomara a nadie sorpresivamente se debió a que fue preparado discursivamente como ineluctable, y basta para dar cuenta de ello la lectura de los principales periódicos en las semanas previas a aquél 24 de marzo. Por lo demás, la prensa fue un actor central en la instalación del "problema de la violencia" asociado a "la subversión", aun cuando la mayor parte de la violencia política se debiera a los grupos paramilitares y al mismo Estado; cf. Franco, Marina, Un enemigo para la nación..., op. cit.

${ }^{9}$ Los términos son los elegidos por los redactores de Clarin, cf. "La culminación de un proceso", op. cit.
} 
Casa Rosada, los editores exhibían otra de la Plaza de Mayo, mientras se señalaba la poca presencia de seguidores del gobierno destituido. ${ }^{10}$

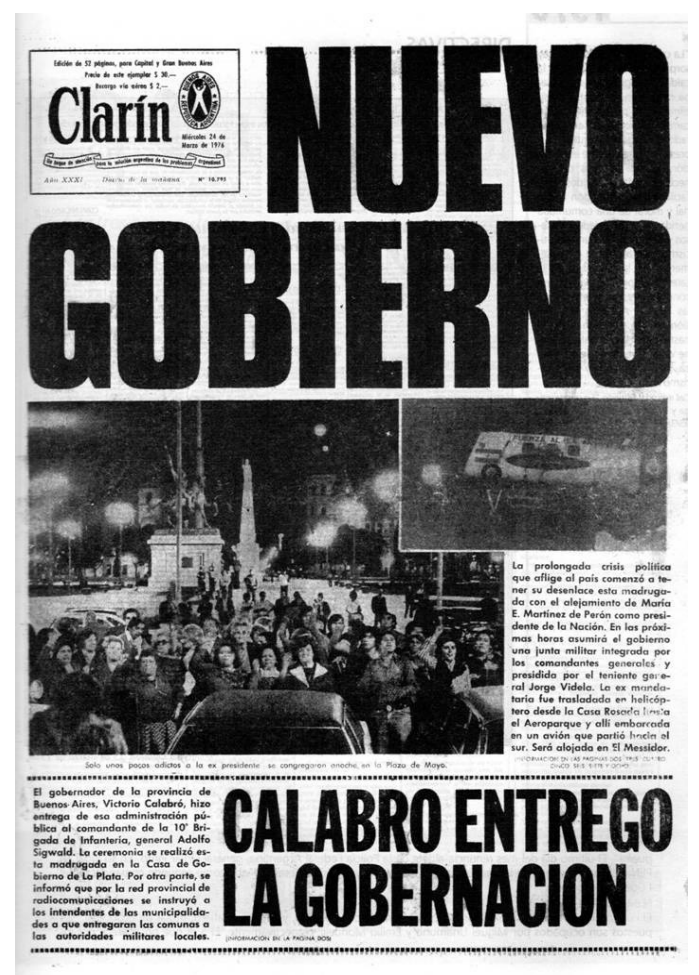

El léxico y las expresiones elegidas por los grandes medios instalaban la lectura de la situación como el pasaje desde el caos y la insensatez al momento de la solvencia y la seriedad, hacia una instancia de cordura y equilibrio. De allí que La Nación, viejo periódico de las clases dominantes, titulara su primera plana de ese 24 de marzo con la frase "Las Fuerzas Armadas asumen el poder; detúvose a la Presidente", donde asumir, si bien significa tomar algo, lo es en el sentido de la responsabilidad, de un deber, una obligación. Los textos e imágenes de los medios gráficos montan los anclajes fundamentales de un razonamiento del momento político (que los lectores podrían tramitar más o menos conscientemente): ante esa plaza vacía que exhibe Clarín, que las Fuerzas Armadas asuman el poder del Estado no sería más que la deriva natural de un proceso que fluye desde una situación de desgobierno y de amenaza hacia la hora de la tranquilidad y el orden. ${ }^{11}$ Quisiera remarcar este punto, paradójico, pues la irrupción de las Fuerzas Armadas en la escena no sólo es indicativa del creciente predominio y la apelación a la fuerza, sino que a la vez ese recurso es presentado como el paso necesario para dejar atrás una situación de violencia y

\footnotetext{
${ }^{10} \mathrm{La}$ foto fue tomada desde la Casa Rosada en dirección a la Plaza de Mayo y en el epígrafe puede leerse: "Sólo unos pocos adictos a la ex presidente se congregaron anoche en la Plaza de Mayo", Clarín, 24 de marzo de 1976. En la fotografía se distingue un primer grupo de unos 30 manifestantes en el que predominan las mujeres, algunas de las cuales se manifiestan gestualmente; más atrás, sobre la otra vereda de la calle Balcarce, una segunda línea de personas (unas diez) siguen la escena más pasivamente, y ya cerca del monumento a Belgrano, se advierte un último grupo de cinco o seis observadores.

${ }^{11}$ Cf. entre otros Corradi, Juan, "The Mode of Destruction: Terror in Argentina", en Telos. A Quarterly Journal of Critical Thought, $\mathrm{n}^{\circ}$ 54, invierno, 1982-1983, pp. 61-76; Franco, Marina, Un enemigo para la nación..., op. cit.
} 
crisis e iniciar una de normalidad y serenidad: en este tránsito de la violencia sin norma (aparente) a la normalidad de la violencia la palabra que ancla los sentidos es orden. ${ }^{12}$

Un ejemplo de esta estrategia discursiva que expone la situación como pasaje de la crisis al orden es la primera plana de Clarín del día 25 de marzo de 1976, donde título y volanta principal rezan “Total normalidad. Las Fuerzas Armadas ejercen el gobierno". Las imágenes que acompañan tal afirmación son la de los tres comandantes que integran la Junta Militar y una fotografía del centro porteño cuyo epígrafe aclara que en "la primera jornada del nuevo régimen (...) la actividad industrial y comercial se desarrolló sin inconvenientes" y que "las calles del centro de Buenos Aires mostraron su aspecto habitual". ${ }^{13}$

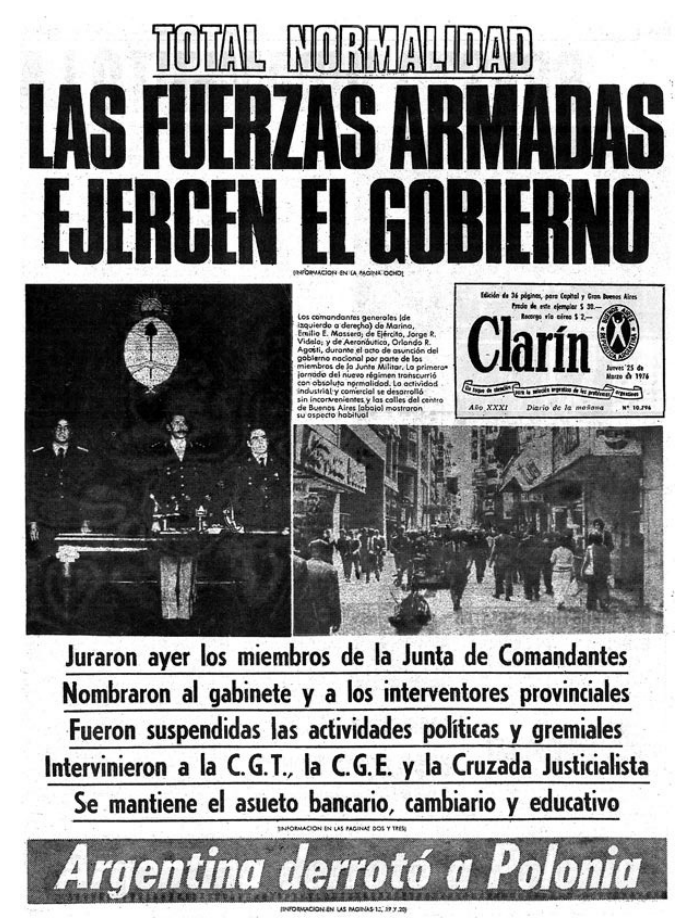

Para los editores, la "normalidad" declarada en la volanta superior no se contradice con la información que esa misma tapa anuncia en su parte baja (donde se advierte la suspensión de las actividades políticas y gremiales y la intervención de la Confederación General del Trabajo), y de hecho lo significativo es que esa "normalidad" reclamada no tiene por referente la legalidad sino algo más profundo, un ordenamiento más primario y como anterior a la ley (en el sentido de que es lo que la funda o aquello que la ley conserva). Es esta una interpretación plausible por la misma estructura visual de esta primera plana, que parece simular una balanza: volanta y título son el fiel del momento, y se sostienen en las dos imágenes que acompañan la tapa; a su vez, es la posición complementaria entre ambas fotografías la que permite estabilizar el montaje de textos e imágenes que finalmente construye una figura de equilibrio, dando una idea de estabilidad de la situación (y con ello de vuelta a la "normalidad"). El enlace entre ambas imágenes no es sólo por

\footnotetext{
12 De modo congruente, el predominio de imágenes y textos sobre la violencia y el caos en la prensa diaria cede su lugar a fotografías que coadyuvan a brindar una idea de paz garantizada por soldados patrullando las calles; cf. Gamarnik, Cora, "Imágenes de la dictadura militar. La fotografía de prensa antes, durante y después del golpe de Estado de 1976 en Argentina”, en Pérez Fernández, Silvia y Gamarnik, Cora, Artículos de investigación sobre fotografía, Montevideo, CMDF, 2011, pp. 49-80.

${ }^{13}$ Clarín, 25 de marzo de 1976.
} 
composición visual; también las conecta un epígrafe compartido, que narrativamente inicia la elucidación de lo que se ve a la izquierda para pasar luego al cuadro de la derecha sin solución de continuidad, estableciendo así un juego complementario entre ambas fotografías. Justamente a la derecha, una vista de la céntrica peatonal Florida (es la calle seleccionada) expone un tránsito de personas en ambas direcciones lo más alejado posible de las representaciones de las movilizaciones sociales. Esta imagen "de la calle" se apoya en la fotografía de la izquierda, donde tres figuras rígidas, la de los comandantes militares de la nueva dictadura -en una composición de la toma que destaca por la simetría- semejan columnas de un nuevo panteón, y en "posición de firmes" pretenden ser los pilares fundamentales de la vuelta al orden y la normalidad; esta imagen a la izquierda de la composición (imagen de la fuerza, no de la ley) juega visualmente como condición de posibilidad -y por eso también de fundamento de un reordenamiento social- que explica tanto el tránsito cansino del peatón como el vertiginoso deambular del agente de Bolsa o del emprendedor comercial que se muestran a la derecha.

El montaje expone, a la vez, que la de los medios es una posición anfibológica: a través de sutiles juegos de vista y de lenguaje pretende mostrar el acontecimiento desde un punto de vista exterior para poder ser un agente de su construcción como instancia legítima (la interioridad de su toma de posición es elidida en ese "modo de exterioridad" de la presentación visual y argumental). El discurso -texto e imagen- adquiere la pretensión de la neutralidad de aquél que muestra una escena como si no estuviera involucrado en el paisaje. Pero justamente se trata de una construcción de la escena, de un recorte y una organización semántica de lo dado, que muestra y dice, a la vez que oculta y calla.

Si alguna violencia es enunciada explícitamente en las tapas de los diarios de esos días es la atribuida a la acción guerrillera o sindical: "En La Plata la acción terrorista fue dominada. En los enfrentamientos habrían muerto 14 extremistas", destaca también en su primera plana de ese 24 el matutino La Nación, haciéndose eco de enunciados que por repetidos configuran una modalidad de diseminación del terror que, si ya hace un tiempo es parte del cotidiano de los periódicos, desde entonces se repetirá de modo sistemático. ${ }^{14}$ Esos modos enunciativos se exponían en la prensa de forma cada vez más uniforme, a través del uso repetido de ciertos términos que iban configurando un léxico que portaba una interpretación sobre situaciones y acontecimientos de aquella actualidad, pero que además ha dejado un legado profundo en las significaciones del pasado reciente. Y mientras el enunciado adquiría el perfil de una "fórmula", los vocablos que como subversivo, extremista, terrorista, etcétera, lo componían, fueron inscriptos en discursos que abarcaban esferas muy variadas de la actividad social; así se nombraba como "guerrilla fabril" al sindicalismo combativo mientras se extendía la actividad subversiva a la cultura o la educación. ${ }^{15}$

Como contracara complementaria, otras palabras eran sustraídas: el elusivo titular de Clarín al designar el inicio de la dictadura como "nuevo gobierno" y la metódica exclusión de vocablos como golpe o dictadura en la prensa escrita, eran parte de un complejo ensamblaje discursivo irreductible a razones de censura o a la moderación de las expresiones. Afirmar que Isabel "fue trasladada" y que luego "será alojada" en el sur, ${ }^{16}$ lindaba la jerga periodística con un lenguaje que,

14 "Hallaron armas en la sede de la UOM", complementa otra noticia de primera plana, esta vez en Diario La Opinión del 25 de marzo de 1976.

${ }^{15}$ La frase "guerrilla industrial" comenzó a circular durante la presidencia de Isabel. Bajo la dictadura el Ministerio de Educación editó un folleto destinado al personal docente titulado "Subversión en el ámbito educativo", una suerte de instructivo destinado a "detectar" personas y conductas consideradas subversivas por sus métodos de enseñanzaaprendizaje; lo subversivo podía incluir, así, a los alumnos, aun a los del nivel inicial. Aunque esto último parezca una exageración, pienso que es sintomático de la idea de lo subversivo que puso en juego la dictadura; volveré sobre este punto más adelante. Cf. Ministerio de Cultura y Educación, Subversión en el Ámbito Educativo (conozcamos a nuestro enemigo), Buenos Aires, MCE, 1977.

${ }^{16}$ Clarín, 24 de marzo de 1976, $1^{\circ}$ edición, copete de tapa. 
a falta de mejor término, designaremos como "eufemístico", el cual, sabemos, tuvo en el centro de detención, tortura y desaparición uno de sus territorios preferidos, donde proliferaban palabras como "quirófano", "máquina", "traslado", "ir para arriba", etcétera. Disposición a un hablar elusivo que exige lecturas sintomáticas: qué (no) se dice cuando se habla o cuando se silencia. Índice de esas formas de nombrar -que como decía, no datan de 1976, sino que, por lo menos, vienen forjándose en los tiempos previos ${ }^{17}$ - capaces de albergar junto a lo que se enuncia abiertamente, un decir latente instituido en la conexión entre la represión y la figura de una nueva subjetividad emergente. El "eufemismo" aparece como una modalidad más de un hablar pseudopolítico que dice a través de una suerte de media palabra, que produce en la lengua política una zona de umbral entre significaciones, entre el enunciado y un sentido velado (pero figurable en el gesto de la ocultación).

Quizás una de sus más citadas ilustraciones haya sido esa frase aparentemente destinada a una conciencia sanitaria: "el silencio es salud" se transformó en un cliché gracias también a una larga tradición discursiva que hizo de la metáfora biológica una de las principales imágenes del orden social. Pero ni esa tradición ni el hecho de contar desde 1975 con una publicística fenomenal para la época (fue reproducida en un enorme anillo que rodeaba el obelisco de Buenos Aires) fueron los motores principales de esa masificación de la frase en cuestión: fue el pacto político que propiciaba bajo coerción el motivo de su conversión en saber popularizado para finalmente ser constitutiva de una figuración subjetiva; un saber que estimaba que si en la Argentina de Videla deberían morir todos los que fueran necesarios para resguardar el orden, era la pérdida de la palabra, de cierta palabra, lo que se exigía para no ser considerado subversivo y lo que se intercambiaba por la vida. Vivir implicaba transformarse en mudo, pero de una cierta mudez, de hondo contenido político. ${ }^{18}$

"Está todo dicho. El final es inminente" es el titular de La Razón del 23 de marzo de 1976. El advenimiento del golpe era considerado en titulares y editoriales diarias de modo sistemático desde meses antes a marzo de 1976. ${ }^{19}$ Que esté "todo dicho" implica que "ya no queda nada por decir", que a su vez puede ser leído como una regulación: "no vamos a decir nada". Orientación a la mudez, al silencio, a callar; que ningún decir (sea palabra o acción) se interponga en lo que viene. Días después del golpe, el 29 de marzo, el mismo periódico anuncia que "Los vecinos empezaron la ardua tarea de limpieza de las castigadas paredes", una nota que, junto otras del mismo tenor, ocupan toda una página bajo el título "Va retornando el orden a Buenos Aires". ${ }^{20}$

\footnotetext{
${ }^{17}$ Cf. Pittaluga, Roberto, “La memoria según Trelew”, op. cit.

${ }^{18}$ Como es el caso del trabajador que interpreta Federico Luppi en la película Tiempo de revancha de Adolfo Aristarain (1981), quien finalmente debe cortarse la lengua para que su intención en el conflicto con la patronal (que es el lugar de su autonomía y también de su pasado como activista sindical) no sea descubierta, y por lo tanto conservar la vida. Hay quienes entienden ese silencio como un acto de resistencia y de fidelidad a los principios, pero me parece más razonable pensarlo como la emergencia de una nueva subjetividad, desentendida ya de su pasado y sus discursos políticos. Pero se trata de un "desentendimiento" provocado por la violencia del "corte", de la pérdida de la palabra y de la lengua, del significado y del significante, de la idea y del cuerpo. Y si finalmente pareciera que en la película la revancha tiene lugar (Bengoa, el personaje de Luppi, gana el juicio, la patronal debe indemnizarlo y sobrevive al conflicto) no ha sido gracias a los viejos ideales sino por los nuevos de la salida individualista; se trata ya de otro Bengoa. No sucede lo mismo con Golo, el personaje de Alberto Benegas, descendiente de los pueblos indígenas (vinculando así dos exterminios perpetrados por el Estado argentino), quien luego de brindar testimonio de solidaridad con Bengoa es asesinado y arrojado a los pies de Luppi desde un automóvil Ford Falcon. Podría decirse que esa nueva subjetividad emergente, la del nuevo Bengoa, se labra sobre una exigencia: el gesto explícito de abandonar aquellas palabras políticas perturbadores del orden.

${ }_{19}$ Vitale, María Alejandra, "Memoria y acontecimiento. La prensa escrita ante el golpe militar de 1976", s/f, en línea en: http://historiapolitica.com/datos/biblioteca/vitale.pdf [última consulta: mayo 2012].

${ }^{20}$ La Razón, 29 de marzo de 1976; cit. en Gamarnik, Cora, "Imágenes de la dictadura militar...", op. cit.. Orden y borramiento de la palabra política; uno como reverso complementario de la otra. Como en el ya recordado anillo que en 1975 rodeaba el obelisco: del otro lado de "El silencio es salud" se conminaba: "Mantenga limpia Buenos Aires".
} 
"Eufemismo" y silencio. A través de estas modalidades emerge un discurso que instituye una zona ambigua por la cual el detrás de la escena se expone por lo que falta y lo que se sabe se oculta o se dice distorsionado. $\mathrm{Y}$ en ocasiones eso que no se dice o no se dice como tal, aflora o se presenta allí donde menos se lo espera, en un margen, como un contrasentido, en un lugar en apariencia no significativo. Es el caso de la primera plana de Crónica del 29 de marzo de 1976, donde la noticia principal es la asunción de Videla como presidente. La fotografía del momento de su discurso "en una breve y austera ceremonia" es contrastada con la violencia guerrillera en la muerte de un jefe policial y en la detención presunta de los sindicalistas Herrera y Miguel. ${ }^{21}$ Sin embargo, el verdadero complemento y a la vez contrapunto de esa ceremonia "despojada" lo constituye la tira cómica "Lolita", ubicada al pie de la tapa del diario: en ella y en ese preciso día, el hombre que mira lo que no debe ser mirado, es desaparecido. Hay, entonces, una preceptiva sobre cómo y qué mirar, o lo que es lo mismo, un mandato del lugar social de cada uno (y con ello de la vista posible); pero a la vez, bajo esta modalidad disfrazada, distorsionada, desplazada, en un lugar marginal de la arquitectura de esa primera plana, apelando al humor, aparentemente ajeno a la noticia del día, se abre paso lo (no) dicho del acontecimiento; emerge allí, como a contramano, en un lugar insólito, lo que (no) se nombra, la desaparición.

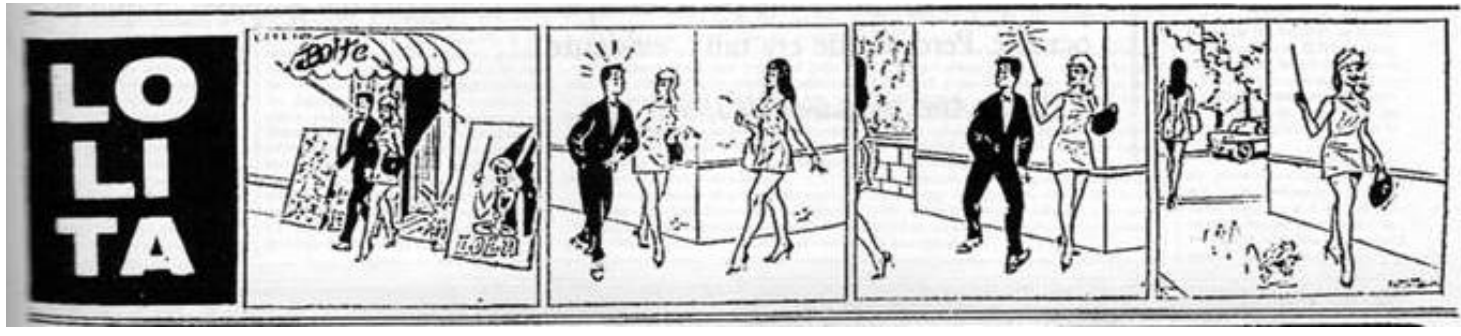

\begin{abstract}
$* *$
Construcción de la mirada. Las imágenes seleccionadas por la prensa gráfica ofrecían también una perspectiva y los objetos de la visibilidad. Y como si lo esencial de lo que sucedería en breve se ubicara en ese lugar conspicuo del poder que se supone es la casa de gobierno, si algo debía ser fotografiado seguramente sucedería allí. Una vista que se sostiene en un imaginario de la política que impone una distribución del espacio y sitúa a los sujetos y sus miradas.
\end{abstract}

Sin embargo, mientras esperaba, y frente a esas imágenes que exponían lo visible (sea la fotografía del helicóptero, la de la plaza vacía de Clarín, la de la Junta o la de Videla asumiendo, todas fotos que buscaban plasmar lo que está delante de los reporteros) Héctor "Puchi” Vázquez hizo otra, mirando a sus espaldas; incluso podría decirse, fijando su mirada en lo que está detrás de la escena visible del golpe. ${ }^{22}$ Según relató muchos años después, empujado quién sabe por cuál fuerza, giró y miró lo que había detrás de sí, y entonces decidió que eso que veía -o que no veía, más precisamente- debía ser captado, testimoniado. Lo que resultó fue una toma que podríamos

Frase esta última que perduraría como acrónimo en el nombre de la empresa de recolección de residuos concesionaria del servicio en la ciudad de Buenos Aires a partir de 1980.

${ }^{21}$ Ambas noticias también en esa primera plana; Crónica, 29 de marzo de 1976.

${ }^{22}$ Fijar, es decir, asegurar, hacer algo estable, delimitar, lo que incluye precisar el sentido. Pero fijar también alude a la fotografía como imagen inalterable, y aun a prestar atención con la mirada. Instancia discursiva de fijación (visual y narrativa, como cuando en un relato el locutor le señala al locutario que se fije para remarcarle algún evento) la intención de Vázquez es establecer un punto de anclaje para las posibles significaciones, asentar un testimonio. Como dijo John Berger: "Lo que, sin embargo, hace la cámara, y el ojo por si mismo no puede hacer nunca, es fijar la apariencia del acontecimiento"; Berger, John, Mirar, Buenos Aires, de la Flor, 1998; subrayado en el original. 
calificar de "invertida", que iba a contramano del foco de la atención pública, que miraba al revés, se fijaba en el tras-fondo.

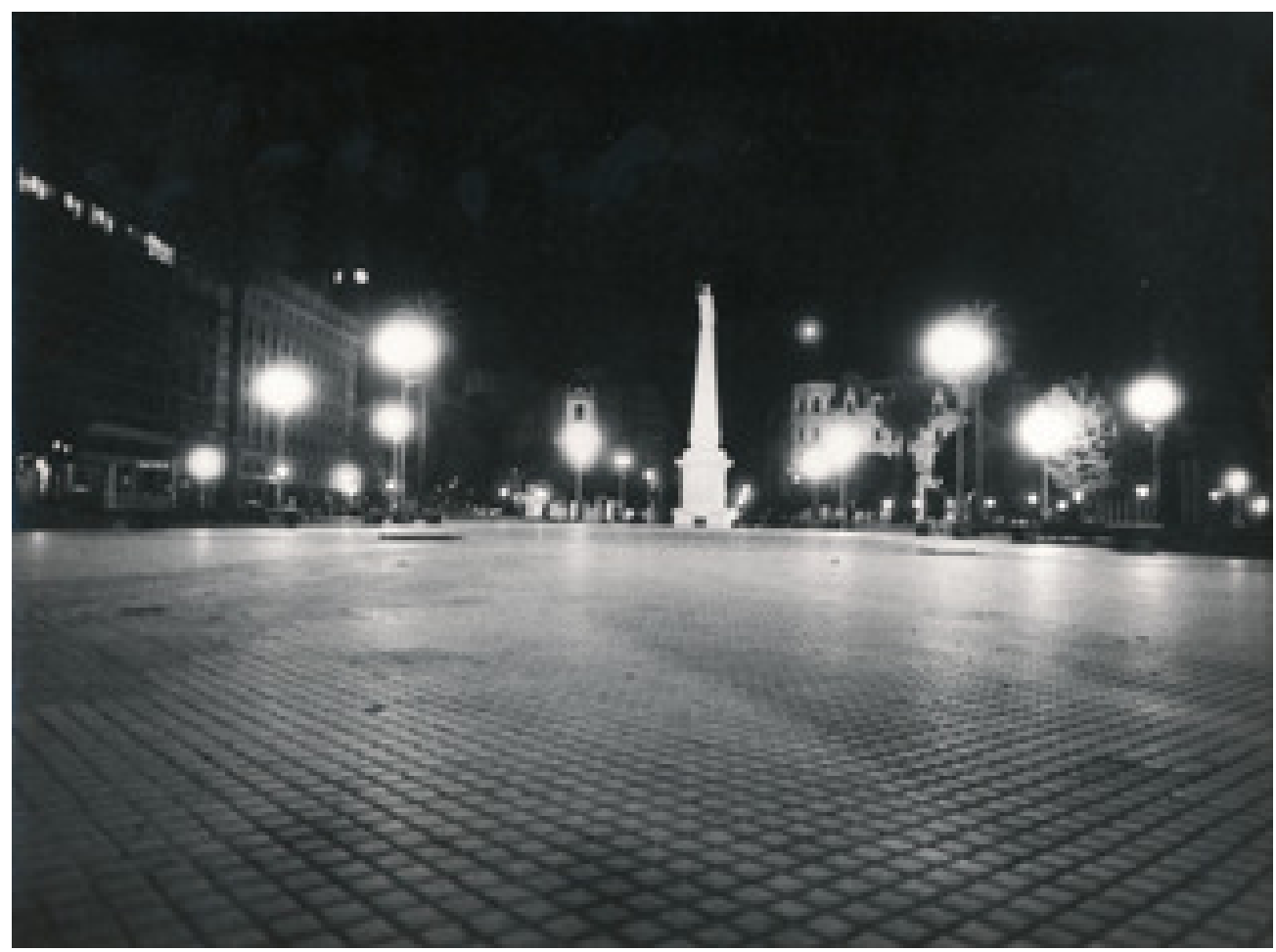

Tal vez allí, en esa otra "plaza vacía", Héctor "Puchi” Vázquez vio algo que era significativo del "golpe", y más aun, de la dictadura. O mejor dicho, no vio algo, y justamente porque no vio, vio; en otras palabras, distinguió (hasta podemos imaginar que lo impactó) un vacío, una ausencia. Es hasta probable que lo que más le sorprendiera era el contraste con las "plazas llenas" de los últimos años, entendiendo por tales una metáfora de esa subjetivación política que se traducía, entre otras cosas, en una "toma del espacio público", o más bien, en una constitución de un espacio público por esos sujetos. ${ }^{23}$ Esa plaza del 24 antagonizaba con aquellas de las movilizaciones de masas, las de la presencia del pueblo. Así, lo que el fotógrafo intentaba captar en la película era, en primera instancia, la ausencia del pueblo. Si la fotografía, como decía Barthes, tiene un efecto de realidad porque lo que quedó fijado, marcado materialmente en la película es un instante efectivamente sucedido, esta fotografía produce otro efecto de lo real, el de señalarnos una falta; es una fotografía que desesperadamente se dirige sobre aquello que ya no sucede. De modo que no podríamos designarla como una foto de la "plaza vacía" sino como el vacío que la plaza denuncia.

\footnotetext{
23 Cuando digo "plazas llenas" y "constitución de un espacio público" no me estoy refiriendo a lo público estatal, propio de las sociedades capitalistas, sino a una dimensión de la política, aquella que erige nuevos espacios hasta entonces inexistentes en donde se trama lo colectivo, espacios que se nombran de distinto modo (como sindicatos, centros de estudiantes, grupos de debate, colectivos culturales, asociaciones barriales, movimientos villeros, etcétera), que siempre se nombran otra vez (como piqueteros, asambleístas, etcétera). Esos espacios pueden ser instancias de administración de los sujetos (es decir, dispositivos de control, más allá de su génesis) o ámbitos de autogestión, o sea, expresiones de fenómenos de agencialidad, de subjetivación que rediseñan el campo de fuerzas de la política (y en este último sentido, pueden ser verdaderamente movimiento comunista, emancipatorio). Generalmente son una mezcla de ambas cosas, que obran como instancias polares de una subjetividad política tensada.
} 
Sartre sostenía que "la imagen es un acto y no una cosa", y a partir de ello Didi-Huberman enfatiza la necesidad de examinar todo el proceso de producción de la imagen, desde las condiciones para lograrla hasta las de su circulación. ${ }^{24}$ Algunos de esos aspectos de la producción de la fotografía pueden deducirse de su enfoque, como por ejemplo la elección del ángulo de la toma. Es evidente que Vázquez se agachó e intentó tomar la imagen desde abajo, como si estuviera "a ras del suelo"; se trata de la elección de una perspectiva que, junto a la utilización de un gran angular, sea capaz de "mostrar" el vacío. ${ }^{25} \mathrm{El}$ efecto visual es la puesta en primer plano de una trama de baldosas de aspecto infinito e infinitamente vacías, pues el resto de los elementos de la imagen parecen retraerse hacia el fondo del cuadro, como si el autor lograra empujarlos a una distancia mucho mayor de aquella que efectivamente los separa del lugar de la toma.

Para construir en la fotografía esa ausencia que Vázquez ve a las espaldas de la escena del día del golpe, no basta con una toma amplia de la plaza. Es que lo que esta imagen expone es otra laguna, un vacío de otro tipo, que para ser captado debe registrarse desde un particular punto de vista, desde abajo. La elección de ese específico ángulo de mira hace de la fotografía una lectura de la situación y no una mera reproducción de aquello que estaba ante la cámara. El evidente aspecto constructivo de la imagen nos incita a quienes la observamos a trabajar sobre su factura, sobre las elecciones del autor para su composición. Estamos ante un material que nos exhorta a que lo interpretemos, que exhibe su carácter de artificio, que desbarata cualquier uso meramente ilustrativo. Por este medio del arte (imagen, perspectiva, angular) su autor intenta registrar y mostrar "lo que no está" en la imagen; aspira a decir una verdad que pretende ser silenciada, ocultada, borrada.

Al elegir ese punto de vista "a ras del suelo", esta imagen se opone a esas otras representaciones de la Plaza de Mayo ya cristalizadas que la han mostrado casi siempre desde arriba, desde una perspectiva cercana al poder (la Casa Rosada, el Cabildo u otra dependencia oficial o de poder de las clases dominantes). Puede decirse que ésta es ya una primera inversión: mirada al revés, es una observación desde abajo de lo que por tradición se configuró visualmente desde arriba, y por ello confronta el marco de representabilidad de la Plaza de Mayo, es decir, de la política como police, al decir de Jacques Rancière.

De todos modos, la elección de esa perspectiva no tiene sólo la motivación política -más o menos consciente- de ser el reverso de la mirada del poder. También puede inferirse que en ese preciso día -contexto de producción - la vista elegida da cuenta de una condición, tal vez intuida afectivamente por Vázquez: ${ }^{26}$ la perspectiva de la imagen es la de alguien que está en el suelo, derribado, abatido. Abatir era un verbo que se repetía en las noticias diarias de la prensa gráfica durante la dictadura y en los años previos: eran abatidos los subversivos, los extremistas, los terroristas. Los fusilamientos y asesinatos aparecían en la prensa bajo esas modalizaciones enunciativas por las cuales todos los días alguien aparecía abatido. Abatido, es decir, derribado, caído, pero también descompuesto en sus partes, des-armado (despojado de sus armas, incluyendo la palabra).

La Plaza de Vázquez: una vista a ras del suelo como podría verla quien ha sido abatido, quien ha caído, quien ha sido tumbado. Pero sabemos que justamente el dispositivo de exterminio ha incluido la negación de la muerte y la imposibilidad de la tumba: el crimen ontológico, el aspecto

\footnotetext{
24 Sartre, Jean-Paul, La imaginación, Madrid, Sarpe, 1984 [orig. 1936], p. 202; Didi-Huberman, Georges, Imágenes pese a todo. Memoria visual del Holocausto, Barcelona, Paidós, 2004.

25 Vázquez ya había realizado una fotografía de la Plaza de Mayo agachándose con la intención de construir la imagen de un vacío: el que dejaron las columnas montoneras el $1^{\circ}$ de mayo de 1974; cf. Testimonio de Héctor "Puchi" Vázquez, op. cit.

${ }^{26}$ En su testimonio de 2005, Vázquez no deja claro cuándo empezó a saber sobre los centros de detención y desaparición, aunque podemos suponer que, vinculado a una organización política y a la vez al mundo periodístico, debió ser tempranamente.
} 
deshumanizante del terrorismo estatal, como señaló Héctor Schmucler. El punctum barthesiano de esta fotografía es esa particular puesta en primer plano de la extensa, ilimitada trama de baldosas de la plaza. La propia imagen queda dividida en dos: la noche y las luces, los monumentos y los edificios, se asientan, se sostienen sobre esa otra mitad de la imagen que son los mosaicos. Ese territorio de la base de la imagen, cuadriculado, casi sin matices (salvo por los efectos de la iluminación) es lo más parecido a una traza homogénea a la que le han borrado los avatares de la historia. Un espacio geometrizado a partir del vacío de la desaparición: la cuadrícula como un tejido (social) ordenado del que se han eliminado las vidas rebeldes y sus marcas, sus huellas, sus pisadas, aun sus muertes. En su lugar, ese espacio con una nueva grafía de carácter uniforme, unas cuadrículas que son una reescritura que pretende no conservar nada del pasado de quienes transitaron esa plaza con tono político, quienes ocuparon plazas y calles con la expectativa de un cambio social.

Sin embargo, habría que decir que allí donde parece predominar una escritura uniforme y ordenada, sobreviven vestigios que requieren un esfuerzo de lectura. El primer rastro, el primer indicio es la misma fotografía, en tanto escritura de una ausencia, de una ausentación forzosa. Una escritura de lo que no está, de lo que falta, la foto es ella misma una marca de la falta de marca. Y ese vacío denunciado en la imagen sólo es perceptible si se lo enfoca desde abajo, y si se trabaja sobre la escena distorsionándola (angular) para mostrar lo que no se ve, lo suprimido. La imagen es un registro construido en su mismo enfoque. Lo que disipa cualquier ingenuidad sobre el lugar del intérprete (el fotógrafo ese 24 de marzo, nosotros hoy), que debe ser activamente productor de esa lectura de rastros que sólo pueden presentarse deformados. Para que esta imagen no sea vista como una imagen nocturna más se requiere de la recuperación de ese trabajo de producción (la acción de la toma en el contexto de la toma) como también seguir la historia de la misma fotografía y disponerse -quien mira- en un "ángulo de lectura", en una perspectiva. ${ }^{27}$

Pensemos en esas baldosas del primer plano de la imagen; volverán a ser transitadas y también marcadas, y sobre ese vacío que la foto retrata emergerá un nuevo activismo político. De lo contrario, ¿cómo comprender que hoy la Plaza de Mayo ostente en sus mosaicos, pintados, escritos, los símbolos de la lucha contra la dictadura, emblemas que nacen como formas primeras de recuperación de una palabra que había sido enajenada, prohibida, olvidada? El mismo nombre de esa plaza está asociado desde entonces a esa lucha y a la recuperación de las historias borradas. Por lo demás, las veredas y plazas de la ciudad pasan a ser, desde hace un tiempo, lugar de escritura de lo que fue ausentado por la fuerza y la violencia. Ya no es posible caminar por Buenos Aires sin que el paso sea interrumpido por esos recordatorios que nos señalan lo que sucedió, nos ofrecen los nombres de aquellos que fueron desaparecidos o asesinados y nos revelan cuánto de nuestro transitar cotidiano se realiza por los mismos espacios por los que circuló el terror y la muerte sistematizada.

La fotografía de la Plaza de Mayo que el 24 de marzo de 1976 tomó Héctor "Puchi” Vázquez es, además, una imagen superviviente. Junto con parte del archivo fotográfico de las publicaciones periódicas El Descamisado y La causa peronista ${ }^{28}$ fue "resguardada" durante la dictadura en un saco de correo depositado en el vagón de encomiendas de la formación ferroviaria que hacía el trayecto Buenos Aires-Tucumán. Durante años, la mentada fotografía fue de Buenos Aires a Tucumán y viceversa, sin que nadie tocara el bolso que según el rumor que corría entre los empleados ferroviarios pertenecía a Montoneros. Como la carta robada de Poe, la fotografía y el

\footnotetext{
27 Pero, como veremos más adelante, se precisa también de un trabajo de circulación, de una exposición que recupere ese marco interpretativo que orienta la toma.

${ }^{28}$ El Descamisado se publicó entre mayo de 1973 y abril de 1974 (46 números, y dos pruebas, los no 0 y 00). Fue reemplazado por La causa peronista, que sólo editó nueve números entre julio y septiembre de 1974, fecha en la que fue clausurado por el gobierno peronista. Vázquez fue reportero gráfico de ambas publicaciones; con posterioridad a las clausuras siguió trabajando como fotógrafo de distintos medios vinculados a la Tendencia.
} 
archivo estuvieron a la vista y por eso ocultos, y quizás eso nos diga algo sobre los modos en que el pasado llega a nuestro presente, es decir, cómo se nos revela. Fue ya en los años del nuevo siglo que María Laura Guembe, por entonces al frente del archivo fotográfico de Memoria Abierta, se interesó en el acervo sobreviviente de Vázquez, y fue en 2006 que esa fotografía pasó a formar parte de una circulación pública de la que antes había carecido, cuando Memoria Abierta la eligió como la foto emblema de su muestra a propósito de los 30 años del golpe. Desde ese año, además de la muestra de Memoria Abierta, exhibida en distintos lugares del país y del extranjero (como Chile y Sudáfrica), esa fotografía también formó parte de los materiales que produjo y de las actividades educativas que sostuvo el equipo "A 30 años del golpe" del Ministerio de Educación de la Nación. Ese peligroso camino que transitó la fotografía de Vázquez ilustra parcialmente cuánto de trabajo, de esfuerzo y de "labor arqueológica" requiere indagar sobre un pasado del que nos llegan testimonios fragmentados, heridos, que exhiben su carácter de sobrevivientes. Lo que implica una delicada tarea de escucha, de lectura de marcas, de interpretación de huellas, de atención a los detalles (pero no como claves de un sentido así revelado y certero sino como instancias de una tarea interpretativa continua y continuada) inscribiendo dichos restos documentales en su contexto de producción.

Esquina de avenida Rivadavia y Miró, en Caballito, Buenos Aires, 17 de septiembre de $1976 .{ }^{29}$ La fotografía registra lo que parece ser el momento en que un hombre mayor espera tranquilamente para cruzar la avenida Rivadavia de sur a norte; al mismo tiempo, tres soldados agazapados, en posición vigilante, parecen aprestarse para un combate próximo, sino inminente. Es justamente esta doble interpretación posible de la escena lo que desconcierta a quien la mira; la imagen congela en un instante lo que parecieran ser acciones que propondrían lecturas divergentes de la situación. Una instantánea de sentidos contrapuestos; una instancia de doble significación, una situación que son dos; ¿carácter constitutivamente paradojal del momento?

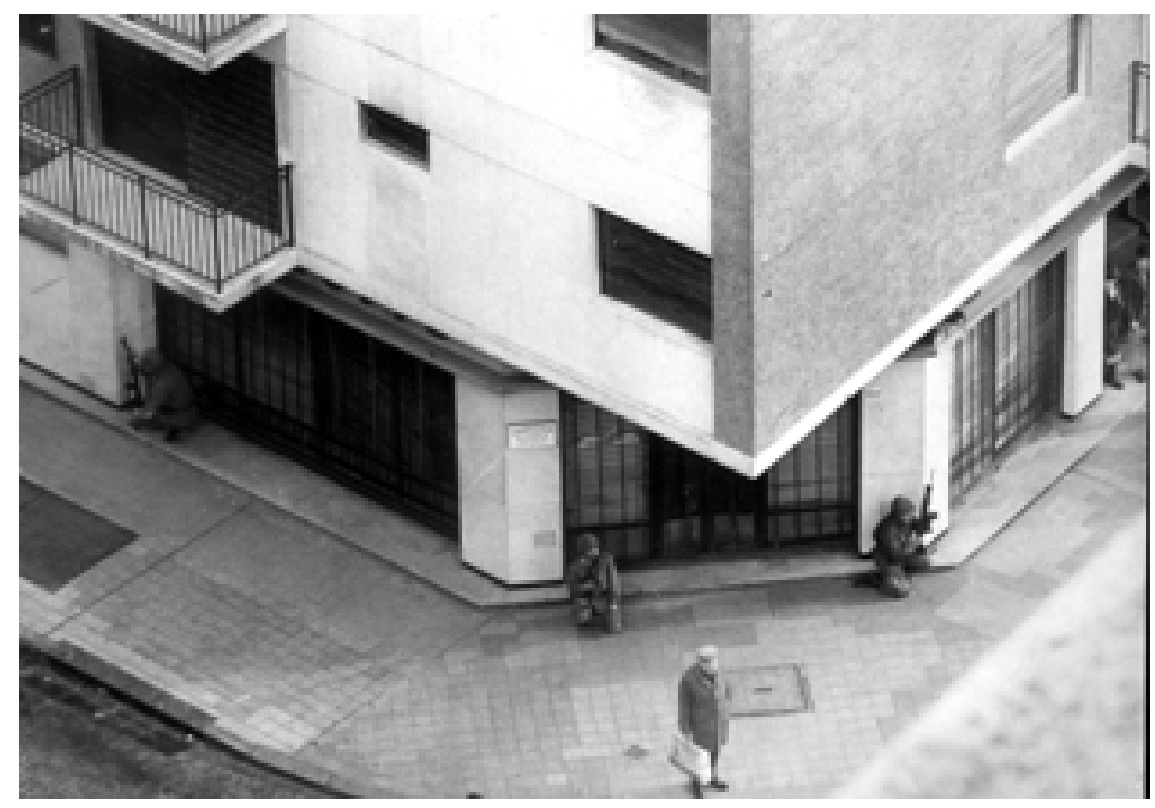

${ }^{29}$ Es la fecha asignada a la fotografía en el archivo de Clarín, al cual pertenece. 
Si hay un operativo militar, como podría deducirse por los soldados apostados cubriendo todas las posibles direcciones (y considerando incluso la amplitud de lo que para la dictadura demandaba una intervención militar) ¿cómo se explica la calma del hombre con su bolsa, esperando cruzar la calle, o la mirada curiosa de la niña y el adulto que la acompaña en el umbral del edificio, a la derecha de la imagen? Si, contrariamente, no hay ningún peligro o amenaza (dada la composición corporal del anciano y la adolescente), ¿a qué obedece la posición de combate de los soldados? ¿Cuáles son los motivos del procedimiento militar? ¿Por qué su despliegue adopta esta forma de un ejercicio de combate ante los transeúntes en una calle de la ciudad?

Lo interesante de esta imagen fotográfica es que esas preguntas no pueden responderse taxativamente. Justamente allí reside su potencia para movilizar el pensamiento al multiplicar las interrogaciones. No es la dificultad por conocer el hecho específico ocurrido esa tarde en esa esquina y que fuera registrado por la cámara lo que la convierte en una imagen inquietante: es la situación paradojal de la cual la foto da cuenta la que moviliza la reflexión sobre algunos aspectos de lo que se ha denominado terrorismo de Estado.

La fotografía presenta unas circunstancias indecidibles justamente a partir de lo que pareciera ser una tensión entre los dos elementos centrales de su vista: el hombre mayor y los soldados. Esta configuración polar de la imagen la torna inestable, tensionada entre lo que se desprendería como sentido por la presencia de dichos personajes. Como si se tratara de una imagen prediseñada, su composición lo indica con una suerte de señalador: el vértice del edificio apunta cual flecha al centro escénico de la fotografía, instándonos a detener la mirada sobre el hombre flanqueado por los soldados.

La imagen se organiza en torno a esas dos figuras triangulares consecutivas: la suerte de flecha que semeja la arista del edificio, y la tríada compuesta por los dos soldados y el anciano, que duplica esa forma triangular; es allí donde la tensión de la imagen se exhibe con claridad. Incluso puede suponerse que, más allá de la intención manifiesta, fue esa tensión lo que quiso captar el fotógrafo, entre la aparente tranquilidad o pasividad del transeúnte y la inquietud que provocan los soldados prestos. Desde su ventana de un piso elevado en el edificio de enfrente (cruzando Rivadavia), el fotógrafo captó una escena de una tarde porteña de $1976 .{ }^{30}$ Una esquina bastante transitada aun entonces, en una de las avenidas más importantes de la ciudad. En ese lugar a la vista se instaló la gestualidad del combate, para ser mostrada. El despliegue represor no fue sólo nocturno, sino también a la luz, y esa visibilidad (parcial) formaba parte del mismo dispositivo represivo. ${ }^{31}$ Esa instalación de la represión en la escena pública actuó como factor de rutinización de la violencia estatal, de su exposición cotidiana como parte del paisaje urbano, como una muestra para el transitar diario, generando una habituación por la cual esa violencia dejaba de ser vista como anómala, y se burocratizaba y normalizaba mientras se subjetivaba como un saber no consciente sobre su continuada vigencia.

Este es, entonces, un modo posible para interpretar el "estado de suspensión" del cuadro fotográfico: la quietud del anciano y la despreocupación de la niña ya no se contradicen con un peligro mostrado en la pose de los soldados, sino que una y otra son la consecuencia de una presencia militar habitual que se exhibe, pero que se lee como protección frente a la amenaza.

\footnotetext{
${ }^{30}$ Que se trata de la tarde se deduce por la disposición de las sombras.

31 Por otro lado, hay que decir que muchos de los operativos nocturnos eran, por eso mismo, notablemente expuestos, pues ocurrían en barrios residenciales, en horas de la noche o de madrugada cuando los ruidos urbanos se habían apagado, con gran despliegue de vehículos y armas, con una presencia avasallante de los grupos de tareas, y con la intención secundaria de provocar una conmoción en los testigos. Esta ex-posición fue tanto una puesta fuera (en la vecindad) del aparato represivo, como una explicación de sus modos y alcances (atendiendo a su etimología, explicar es desplegar, hacer presente lo latente). Exposición/explicación que se tradujo, entre otras cosas, en un saber popular capaz de reconocer el aparato represivo, saber cuándo y sobre qué no preguntar, saber qué era un "falcon verde", etc., hasta, finalmente, justificar su accionar ("por algo será").
} 
Justamente la posición de combate acentúa el carácter performativo del lenguaje represivo, significando la situación de modo dual, como protección y amenaza. Es la escritura de los cuerpos de los soldados como en la guerra lo que diferencia el modo de la presencia militar, exhibiendo un activismo con intención de rediseño de la habitación de la ciudad y del tránsito de la calle (es decir, de la política) a partir de la conversión de cada escena en una situación de permanente peligro y violencia. El carácter intimidante de cualquier presencia militar -en casi cualquier contexto- es aquí suplementado, y desplazado, por esta co-locación del cuerpo militar que emplaza en el ambiente una amenaza inminente que aparenta provenir de todas las direcciones y que por esos medios se postula como inmanente a la calle.

Compositivamente, la imagen registra que ese hombre que espera "está custodiado"; su "tranquilidad" - como la curiosa y a la vez desentendida mirada de la adolescente- bien pueden ser, en parte, productos de la rutinaria exposición desnuda de la violencia estatal que se muestra y enuncia como protección (el hombre, tranquilo porque se siente protegido). ${ }^{32}$ Una fotografía que permite pensar algunas de las relaciones entre dictadura y sociedad: cómo una presencia agazapada de la pura fuerza se inscribía más permanente y molecularmente y se naturalizaba en los cuerpos ciudadanos.

Si, como sugiere Didi-Huberman (2004), se restringe el punto de vista para no dejar nada de la sustancia de la fotografía sin analizar, ciertos detalles de la escena parecieran haber sido colocados deliberadamente a fin de dar cuenta de las conexiones entre lo expuesto y lo oculto como medios de irradiación de un terror que al abarcar todos los ámbitos sociales los reconstituía, y en esa faena (pues de eso se trató) moldeaba nuevas figuras de subjetividad. El local comercial sobre el que están apostados los soldados, como lo dice su pequeño letrero, es una carnicería y su nombre no podría ser más acorde: La Perla. ${ }^{33}$

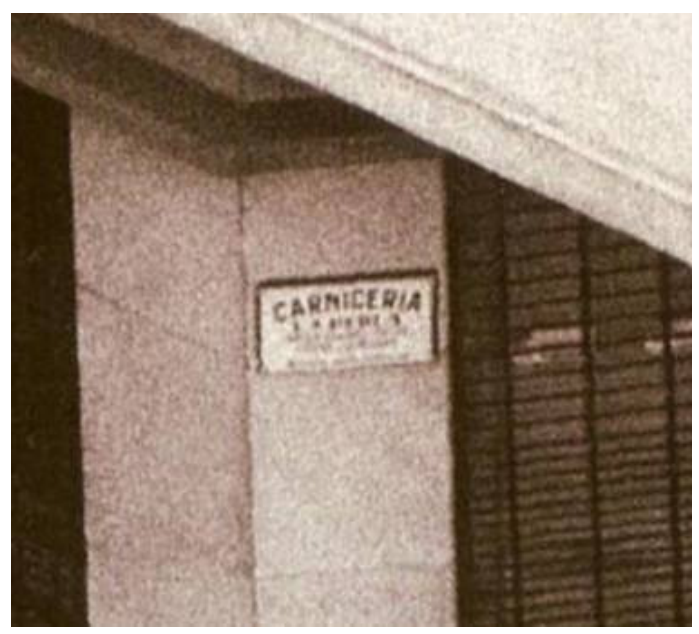

\footnotetext{
32 La figura de subjetividad del "ciudadano-protegido" — que demanda protección para su vida y sus bienes- es una de las emergentes de las transformaciones sociales de los años '70 y ’80, no sólo en Argentina.

${ }^{33}$ Con el nombre de "La Perla" se conoce al mayor campo de detención y exterminio que la dictadura estableció en la provincia de Córdoba, bajo el mando del III Cuerpo de Ejército. El mismo comercio perdura hasta hoy, 2012. Fue en una actividad en la ciudad de Corrientes, organizada por el equipo "A 30 años del golpe" del Ministerio de Educación en 2006, con la presencia de docentes y estudiantes de diversos Institutos de Formación Docente de la región del Noreste y en la que participó Pilar Calveiro, cuando se puso el foco en este "detalle" de rubro y nombre del comercio.
} 
La coincidencia de significantes dice, cuando la lengua parece enmudecer o habla eufemísticamente. Es sobre ese fondo de exterminio y centros clandestinos de detención y desaparición que se presentan los soldados apostados, custodios del hombre de la esquina. Primer plano y fondo de la protección. ¿Estamos entonces ante una "tranquilidad", la de ese hombre mayor, la del gesto adolescente, que es vicaria del dispositivo concentracionario? ¿Una serenidad derivada de la composición de la escena dictatorial, en la cual se amalgaman la gestualidad expuesta de la violencia y los síntomas de su lado oculto? ¿Estamos ante la compleja convivencia subjetiva del sosiego y del terror? ¿Cuáles figuras de la subjetividad podrían dar cuenta de estas circunstancias?

El hombre está solo, y no es una circunstancia indiferente a la interpretación de la situación; esa soledad también está dispuesta en la composición fotográfica como un énfasis visual. Hannah Arendt señalaba que el terror sólo puede reinar sobre hombres aislados, pues éstos carecen de poder por definición; de modo que la primera preocupación de las dictaduras es la producción de esa soledad, de ese aislamiento. Por eso Dardo Scavino nombraba agudamente a la dictadura y la posdictadura argentinas como "la era de la desolación", la de los sujetos a solas, asolados, desolados, des-solidarizados. ${ }^{34} \mathrm{El}$ hombre a-solas (desolado por el exterminio y el terror) ha sido uno de los más altos objetivos y logros de la dictadura: una nueva subjetivación se produjo entonces (por supuesto que sobre la base de tendencias preexistentes). ${ }^{35}$ Fracturados los anteriores vínculos comunitarios por la violencia estatal, el hombre de la fotografía está solo frente al Estado, que exhibe su rostro más amenazante, el poder militar, pero no únicamente como poder de muerte sino también como poder desaparecedor. Esta profunda reformulación de la trama social era apuntada tempranamente por los voceros del régimen: al "escarmiento histórico" de Videla, Martínez de Hoz, ministro de Economía, añadía que "el cambio propuesto era muy profundo; no bastaba con un simple proceso de ordenamiento, sino que había que transformar normas y marcos institucionales, administrativos y empresariales; políticas, métodos, hábitos y hasta la misma mentalidad". "La violencia sistemática fue dirigida a desarticular los colectivos de pertenencia y de intervención política, cultural, etc., que habían nacido como expresiones de rebeldía y anhelos emancipatorios. La destrucción incluyó las palabras, que fueron proscriptas o mutaron sus significados. El costado destructivo era complementado por uno productivo: el hombre a-sola-do no es un ser al que se lo ha despojado de toda relación con otros, sino que se halla inscripto en otro vínculo social, una nueva trama de relaciones que se conjuga en una nueva subjetividad y en una nueva palabra.

La violencia y el terror de Estado no sólo arrasaron casi todas las formas de solidaridad; como señaló Scavino, desolar, además de destruir o devastar, también significa angustiar, afligir o atormentar. Y Jorge Jinkis sostuvo que "la catástrofe asesina ha infiltrado el miedo en nuestros cuerpos". ${ }^{37}$ Existe un consenso en torno a que entre los objetivos de la dictadura estaba la pretensión de construir generaciones con miedo. Héctor Schmucler anota que un oficial de marina, poco después del golpe de 1976 le dijo a Jacobo Timerman, entonces detenido, que si se exterminaba a todos los guerrilleros "habría miedo por varias generaciones". ${ }^{38}$ Como se ha dicho,

\footnotetext{
${ }^{34}$ Scavino, Dardo, La era de la desolación. Ética y moral en la Argentina de fin de siglo, Buenos Aires, Manantial, 1999 , p. 77.

35 En la novela Villa, Luis Gusmán examina en profundidad el complejo territorio subjetivo sobre el que pudo sostenerse la deriva represiva y autoritaria que finalmente desembocó en el terror estatal. Cf. Gusmán, Luis, Villa, Buenos Aires, Edhasa, 1996.

${ }^{36}$ Cf. Martínez de Hoz, Alfredo, Bases para una Argentina moderna: 1976:1980, Buenos Aires, ed. del autor, 1981, cit. en Dussell, Inés, Finocchio, Silvia y Gojman, Silvia, Haciendo memoria en el país del nunca más, Buenos Aires, Eudeba, 1997, p. 19.

37 Jinkis, Jorge, Violencias de la memoria, Buenos Aires, Edhasa, 2011, p. 40.

38 Schmucler, Héctor, "Usos políticos del miedo", en AA.VV., Miedos y memorias en las sociedades contemporáneas, Documentos de trabajo del Seminario de trabajo, Córdoba, UNC/Núcleo Memoria IDES/ComunicArte, 2006, p. 294. Schmucler toma la cita de Jacobo Timerman, Preso sin nombre, celda sin número, Buenos Aires, Random, 1981.
} 
la tortura, además de los propósitos de obtención de información, pretendía doblegar la confianza entre compañeros, quebrar la amistad y reconducir el vínculo hacia el desamparo y la desconfianza, esto es, producir "un nuevo sujeto". ${ }^{39}$ De modo que existió una correspondencia entre la sala de torturas y el desmantelamiento de las formas de vida comunitaria, especialmente aquellas basadas en la cooperación: bien podríamos concebir a esa figura solitaria del hombre detenido en la esquina como la emergente figura de la subjetividad que la dictadura se propuso forjar. Al remodelar la trama social tras estos propósitos, el "terror de Estado" engendró un "estado de terror".

Un miedo infiltrado en el cuerpo, dice Jinkis. Lo que puede leerse como un miedo que se aloja en el interior, que no es visible a simple vista ( $\mathrm{y}$ no debe ser exhibido como tal por quien lo sufre). Esta figura de subjetividad, incapaz de mirar lo que sucedía (ni de mostrar el miedo infiltrado), sería congruente con esos testimonios que señalan la parálisis, la des-vinculación social y una suerte de encierro en el micromundo familiar. De todos modos, si podemos hablar de una "subjetividad aterrada" es bajo la condición de pensarla -siguiendo a Héctor Schmucler y Susana Kaufman-como un permanecer primitivamente adherido a la tierra, es decir, fijado a un lugar y a un comportamiento sociales, y, a la vez, como una existencia fracturada, disociada, tras-tornada por el impacto de la violencia generalizada. ${ }^{41}$ Una condición que se ha expresado como un saber lo que sucedía mientras simultáneamente se lo negaba. El saber que subyace al no querer saber, a los distintos modos de la negación, es un saber que no quiere enfrentarse con aquello que lo hace semejante con los agentes que ponían en funcionamiento los mecanismos del terror, con la dimensión barbárica de la cultura de la que forma parte.

$Y$ es que el poder represivo interpelaba (entre varios modos) por contigüidad: una vecindad invisibilizada (está a las espaldas del anciano de la fotografía) y a la vez mostrada, sabida. ${ }^{42}$ Quizás

${ }^{39}$ Calveiro, Pilar, Poder y desaparición. Los campos de concentración en Argentina, Buenos Aires, Colihue, 1998, p. 71; cf. también Scavino, Dardo, La era de la desolación..., op. cit..

${ }^{40}$ El término "terror" ha sido empleado de modos diferentes a fin de dar cuenta de la denominación "terrorismo de Estado". Aquí utilizo la expresión "estado de terror" como una suerte de humor producido por el terrorismo de Estado, como una densidad del espacio social, una condición, un medium a través del cual se interpela a los sujetos a partir del núcleo primordial del dispositivo represivo (los campos de detención y desaparición de personas), un campo de fuerzas que orienta a los sujetos a seguir patrones de comportamiento admitidos a partir de esos puntos principales de ejercicio de la fuerza. Desde ellos, y a partir de su específica forma de implantación y actuación, el terror se irradia hacia el conjunto social, afectando de distintos modos las relaciones sociales, penetrando en, diseñando a y/o nutriéndose de materiales sociales y culturales que presentan receptividades disímiles (reflexiones, refracciones, internalizaciones, aceptaciones, etc.) y que se manifiestan en conductas divergentes. La variación de estas afectaciones (que abarca un amplio abanico que va desde el comportamiento como kapos -en la terminología que adopta O'Donnell- hasta el de quienes ejercen toda posibilidad de resistencia, pasando por las distintas instancias intermedias) seguramente se enriquecería a partir de las reflexiones psicoanalíticas (freudianas y lacanianas) de nociones como Furcht, Angst, Schreck, Angoisse, pues abren la posibilidad de conectar la política del terror con centro en los campos y las formas de materialización subjetiva en figuras variadas de dicho terror. Se trata entonces de pensar las conexiones y articulaciones entre el "terror de Estado" como política represiva específica y sistemática, el "estado de terror" como medium así generado (que actúa como un dispositivo y entonces como una disposición), y las distintas formaciones subjetivas (cuyas variaciones y combinaciones podrían dar cuenta de porqué un mismo individuo que reproducía/legitimaba la situación con sus acciones o inacciones cotidianas era también capaz, en cierto momento, de resistirla). Caben aquí las precauciones que formulara oportunamente Elizabeth Jelin en relación a la variabilidad de estas afectaciones del terror y el miedo a través de la trama de los clivajes sociales. Cf. O’Donnell, Guillermo, "Democracia en la Argentina: micro y macro", en Oscar Oszlak (comp.), "Proceso", crisis y transición democrática, tomo I, Buenos Aires, CEAL, 1984, pp. 13-30; Jelin, Elizabeth, "A veinte años del planteo de una 'cultura del miedo' ¿son los mismos miedos? Notas (muy preliminares e incompletas) para una discusión”, en AA.VV., Miedos y memorias en las sociedades contemporáneas, op. cit., pp. 57-63.

${ }^{41}$ Schmucler, Héctor, "Usos políticos del miedo", op. cit.; Kaufman, Susana (2006), "Miedo. Perspectivas subjetivas y lazo social”, en AA.VV., Miedos y memorias en las sociedades contemporáneas, op. cit., pp. 181-188.

${ }^{42}$ Cf., entre otros, Calveiro, Pilar, Poder y desaparición..., op. cit.; Jelin, Elizabeth y Kaufman, Susana, "Los niveles de la memoria: reconstrucciones del pasado dictatorial argentino", en Entrepasados. Revista de historia, año X, n 20/21, 
tanto como de esa solicitud de protección y orden frente a la amenaza de la "violencia subversiva" (demanda que fue efecto de la amplia y sangrienta represión militar y paramilitar de los años previos al golpe), el "estado de terror" del sujeto, esa emergente figura de una "subjetividad aterrada", hayan provenido de su no separación respecto del dispositivo del terrorismo de Estado, de su convivencia, de la proximidad entre el ciudadano y el campo de concentración. Tan poco separado del funcionamiento terrorista del Estado -ésa era, al menos, la pretensión de la dictadura- que su deseo procuró ser configurado por esa presentabilidad del poder desaparecedor. Una propaganda del régimen rezaba "Proteger es querer"; si proteger era querer, entonces podemos leer la frase también de modo invertido, y la interpelación del poder se tornaba deseo de protección, generaba un querer ser protegido que brindaba cierta legitimidad al régimen a través de un deseo que se declara como anterior (y como consensual) al golpe y a la represión. Desde esa lectura, el anciano de la fotografía, custodiado y aterrado, protegido y disociado, que sabe y niega, sería el punto donde se asienta la violencia estatal desplegada, el vértice sobre el que se apoya ese triángulo escénico de la imagen, uno de sus focos de legitimidad. ${ }^{43} \mathrm{Y}$ la inquietud que su figura provoca a quien mira la fotografía es porque en ella reconocemos también nuestras poses cotidianas, cada vez que salimos tranquilamente de compras.

Lo que nos deriva hacia otra preocupación, ¿no es acaso también posible pensar que la tranquilidad del hombre de la fotografía expone una figura de subjetividad que no se construyó sobre el par terror/protección? La composición relajada de las disposiciones corporales expresarían entonces la serenidad de quienes dominan la situación, y más que efectos de la violencia sistemática paralegal y estatal, serían los fundamentos sobre los que aquellas fueron posibles. Guillermo O'Donnell, en un muy citado trabajo sobre la sociedad durante la dictadura, destaca esas conductas debidas a distintos actores que ensamblaban consistentemente con lo prescripto por el régimen dictatorial, conductas que eran tanto el soporte de dicho régimen como uno de sus resultados. Un comportamiento de kapos: así denomina O’Donnell a algunas de aquellas actitudes, estableciendo entonces una relación de afinidad entre el sistema concentracionario de los centros clandestinos y una sociedad que "se patrulló a sí misma", que se comportó como un gran campo de concentración. La penetración capilar en la sociedad de las prácticas represivas de la dictadura -señala O’Donnell- implantaban también allí el orden y la autoridad como relaciones calcadas de la visión radicalmente autoritaria, vertical y paternalista del régimen. ${ }^{44}$ Pero podríamos decir, en rigor, que más que implantar, lo que la política de terror lograba era fortalecer y hacer pasar al primer plano de los vínculos cotidianos las relaciones de dominio autoritarias, jerárquicas y opresivas ya presentes en la sociedad argentina: "Fueron kapos a los que, asumiendo los valores de su (negado) agresor, no pocas veces los vimos yendo más allá de lo que ese muy autoritario régimen demandaba", dice O’Donnnell. ${ }^{45}$ Pero los kapos, a pesar de todos sus privilegios y de la función represiva que cumplían, eran de todos modos deportados, prisioneros. Víctima y victimaria es la doble configuración que otorga Calveiro a la sociedad argentina de entonces: víctima de un terror estatal que la misma sociedad contribuyó a generar. En tanto la estatalidad no es una exterioridad "que se impone" a las relaciones sociales sino una

Buenos Aires, 2001, pp.9-34; Levín, Florencia, “Arqueología de la memoria. Algunas reflexiones a propósito de Los vecinos del horror. Los otros testigos", en Entrepasados. Revista de bistoria, año XIV, n 28, Buenos Aires, 2005, pp. 47-63.

43 Schmucler ha alertado sobre una transposición no problematizada de la noción de miedo o similares al espacio político, pues su inmediata consecuencia sería la anulación de la responsabilidad; Schmucler, Héctor, "Usos políticos del miedo", op. cit., p. 289. Aun cuando pienso que la misma noción de responsabilidad debe ser también problematizada, despojándola de sus rasgos jurídicos para afirmar sus dimensiones éticas y políticas, es posible como señala Blas de Santos- un acercamiento comprensivo a los actos y hechos que coadyuvaron a la emergencia de una formación subjetiva sin por eso "absolverla de toda relación con ellos"; cf. de Santos, Blas, La fidelidad del olvido. Notas para el psicoanálisis de la subjetividad militante, Buenos Aires, El Cielo por Asalto, 2006, p. 58.

${ }^{44}$ O’Donnell, Guillermo, "Democracia en la Argentina: micro y macro", op. cit., p. 17.

${ }^{45}$ O’Donnell, Guillermo, "Democracia en la Argentina: micro y macro”, op. cit., p. 17. 
dimensión de las mismas, la violencia terrorista del Estado interpelaba su sustrato social permanente y originario, e incluso su particular historia argentina. A la hora de pensar, se trata entonces de evitar el riesgo de transformar lo que es una correlación entre terror estatal y sociedad en un vínculo de causa a efecto. ${ }^{46}$

El carácter indecidible de la "tranquilidad" que la imagen nos presenta es lo que hace de este testimonio fotográfico uno inquietante, que incomoda. La imagen no nos da acceso a la verdad de la dictadura y de la sociedad de entonces, pero sí nos acerca un instante de esa verdad, una parte, una instancia, un aspecto: el lugar compartido, entramado, de mutua realimentación entre normalidad cotidiana y violencia represiva. Una imbricación no sólo temporal sino también espacial: a diferencia de otros casos, en la Argentina los centros de detención y desaparición no tenían un lugar explícitamente asignado -como sí los tuvieron otras experiencias concentracionarias en las cuales los perímetros de los campos se recortaban nítidamente respecto del resto de las instituciones y de la vida social-. En la Argentina funcionaron en dependencias públicas o privadas destinadas a otros fines, sin paralizar su normal desenvolvimiento: unidades y regimientos militares, dependencias policiales, escuelas militares, casas y quintas en barrios residenciales, hospitales, fábricas y empresas, instituciones educativas, comercios y galpones, etcétera. Sin dejar de existir, esa frontera entre el centro clandestino y el resto de la sociedad resultaba sumamente porosa: lo que Calveiro denomina sistema concentracionario tuvo una estructura de enraizamiento y permeó al conjunto social, a la vez que se nutrió de él. Un atributo particularmente significativo del régimen (porque fue relevante en la política de desaparición) permite decirlo mejor: muchas detenidas-desaparecidas embarazadas eran llevadas a parir a centros hospitalarios y contaron con la asistencia del personal de planta; todo el sistema de apropiación y desidentificación de los hijos e hijas de los secuestrados contó con un red ramificada en el poder judicial y en la sociedad civil (desde importantes estructuras eclesiásticas a organizaciones no gubernamentales de caridad o similares). De modo que cabe la pregunta: ¿dónde termina el dispositivo de desaparición si la apropiación y desidentificación de niños requiere del aparato oficial (no clandestino) del Estado y/o la sociedad civil (y cuándo si todavía hay cientos de personas ahora adultas que no conocen abiertamente el signo particularmente violento de su nacimiento y/o primera niñez)?

Muchos de los centros de detención y concentración, con su práctica sistemática de tortura, estaban en el medio de la ciudad, ${ }^{47}$ en barrios cuyos vecinos no podían sino escuchar los gritos de los torturados, barrios que, de todos modos, vivían sus días normalmente. ${ }^{48}$ Bien podría afirmarse que el conjunto del sistema represivo que implementó la dictadura no operó solamente en los lugares que se retiraban parcialmente a la vista pública, sino que requería de su inscripción en la trama de funcionamiento social cotidiano. Esta convivencia entre el centro de tortura y

\footnotetext{
46 El término "sociedad" resulta un obstáculo a la hora de indagar las complejas correlaciones entre el terrorismo de Estado y los modos diferentes de su aplicación y recepción entre clases, sectores sociales, espacios culturales y políticos.

47 Como los campos estaban "en medio de la sociedad, "del otro lado de la pared”, dice Calveiro, requerían (y producían) "una sociedad que elig[ió] no ver", una "sociedad desaparecida”; una sociedad paralizada, agrega la autora; Calveiro, Pilar, Poder y desaparición..., op. cit.., p. 147.

48 Como relata Tamburrini, si él escuchaba, durante el día, las voces de los niños saliendo del colegio o la del heladero, cómo no iban a escucharse los gritos de dolor bajo tortura de los detenidos en Mansión Seré, en pleno Morón. Cf. los testimonios del video Los vecinos del horror. Los otros testigos, y el análisis de Florencia Levin, "Arqueología de la memoria....", op.cit., donde la autora, entre otras cosas, afirma: "Lo que estos testimonios nos muestran es que algo de la clandestinidad de los centros de tortura desbordaba y penetraba el barrio dejando rastros que eran percibidos por los vecinos tanto en forma visual como auditiva". Sirve como analogía la imagen que formulara Simone de Beauvoir cuando explicaba que vivir bajo la ocupación nazi de Paris había sido a la vez infinitamente peor y mucho más normal de lo que se podría imaginar. El video Los vecinos del horror. Los otros testigos fue realizado en 1996 con idea de María Cantino y Graciela Guilis, y guión de Genaro Press.
} 
desaparición, y la labor corriente de las instituciones públicas y privadas no iguala todas las situaciones (nadie sostiene que la presencia militar en la fotografía pueda ser comparada con la violencia en el centro de detención y desaparición): lo que produjo este andamiaje fue, por una lado, la diseminación del terror de los centros clandestinos hacia el conjunto de la sociedad -ese "secreto a voces" del que habla Pilar Calveiro- a través de esas vías capilares por las que el dispositivo concentracionario se presenta en las condiciones "normales" de la sociedad. ${ }^{49}$ Por otro lado, y correlativamente, esa faz represiva que se enraizaba en el cuerpo social al desplegarse por muy variados canales producía las condiciones de su aceptación al interpelar las dimensiones de las subjetividades sociales que la hacían posible.

La fotografía de Rivadavia y Miró posibilita pensar la complejidad de esas condiciones por las cuales la sociedad soportó el terror (fue víctima y además lo sostuvo), porque denuncia también el lugar del miedo, que sigue siendo constitutivo de esa situación registrada en un negativo. Quien tomó esta fotografía sabía del oficio; probablemente se trate de un reportero gráfico pues el negativo es parte del archivo del diario Clarín. Lo que explica el casi perfecto equilibrio de la composición de la imagen, perturbado solamente por un detalle cuya presencia es también un indicio para la interpretación de la fotografía. En el margen inferior derecho puede verse parte del alféizar de la ventana desde donde se realizó la toma. Ese "descuido" compositivo puede ser interpretado en función de la acción: podemos suponer que el fotógrafo no quiere ser visto mientras mira y registra. ${ }^{50}$ Es el temor de la situación (tal vez de esas circunstancias específicas que observa; más en general. de la realidad bajo la dictadura) lo que introduce ese alféizar en la imagen. Y a la vez, el detalle del alféizar es la incorporación, en la escena, de la resistencia, pues acredita el momento de riesgo que la toma implicaba. Indicio del valor de ese acto: del valor necesario para realizarlo (a pesar del miedo y del riesgo de ser visto), como de su valor testimonial, documental, pues abre un mirilla hacia esa verdad de la época, brindando un soporte material para otra memoria. Podrá parecer insignificante este acto de resistencia que fuera tomar la fotografía frente a la magnitud de la violencia estatal, pero como todo aquello que dejó testimonio de lo vivido es un elemento fundamental que refuta un aspecto del procedimiento de exterminio: su olvido. Por lo demás, hay también que decir que es el miedo del fotógrafo el que brinda la posibilidad de mirar y mostrar la situación, transformándose en una condición de conocimiento: mientras la tranquilidad del hombre mayor o la niña (en cualquiera de las figuras de subjetividad analizadas) se sostiene en una negación de lo que se sabe o en una indiferencia de lo que se ve, es el miedo -asumido como tal- de quien produce el registro el que posibilita mirar la verdad de lo que sucede.

Esa tensión del instante que se registró en esta fotografía es la que deriva de una ambigüedad, de una situación sobre la que no puede decirse que haya una sola lectura de actitudes, significados, posiciones, relaciones. Entonces, ¿cómo saber, cómo construir un saber de lo sucedido? Pareciera que frente a esta imagen de la fotografía -como ante otras imágenes y otros materiales- estamos

\footnotetext{
49 Sobrevivientes de la ESMA (Escuela de Mecánica de la Armada) han testimoniado que se cruzaban con personas que desarrollaban allí sus actividades diarias; en el Departamento Central de la Policía Federal en Buenos Aires, las oficinas administrativas y el área "clandestina" estaban pared de por medio, y los detenidos escuchaban las máquinas de escribir (cf. el testimonio de María del Socorro Alonso en Memoria Abierta, 2001); también algunas detenidas trabajaron "legalmente" - mientras continuaban en condición de secuestradas/desaparecidas- en distintos ministerios públicos; cf. Actis, Munú; Aldini, Cristina; Gardella, Liliana; Lewin, Miriam y Tokar, Elisa, Ese infierno. Conversaciones de cinco mujeres sobrevivientes de la ESMA, Buenos Aires, Sudamericana, 2001.

${ }^{50}$ Como señalaba más arriba, bien podría decirse que la forma de ver la violencia de la escena -para que se encarne, para que tome cuerpo en esa subjetividad consensual a la dictadura- es la del anciano: de espaldas, como si se tratara de una presentabilidad invisible. Mirar -y por eso ser capaz de mostrar- implicaba otra posición del sujeto que observa, que es lo que hace el fotógrafo. Mientras en la foto de Vázquez éste mira a sus espaldas para mostrar, lo que mira este otro fotógrafo es "a las espaldas" del anciano.
} 
ante una tarea donde el pensamiento naufraga, se pierde, y se desliza hacia especulaciones que alguien podría calificar como vanas. Pero como sostenía Hannah Arendt, donde fracasa el pensamiento es preciso obstinarse en él. Quizás en este caso no se trate tanto de un material para el incremento de nuestro saber sino, por el contrario, de lo que incomoda nuestro saber. $\mathrm{Y}$ es precisamente su instancia de verdad (ser un instante de verdad) lo que produce ese cortocircuito en los saberes instituidos, en las nociones y las ideas con las que pretendemos abordar una experiencia que, por esas vías, siempre se nos escapa. El potencial de estos documentos es tal que, justamente, provoca una descomposición de ese saber, expone sus lagunas y sus insuficiencias. $^{51}$

El miedo, consciente o no, fue también un medio para calibrar las posibilidades en cada situación ante la presencia diaria y masiva de la violencia estatal. Como se mencionó más arriba, uno de los efectos del terror de Estado fue la ruptura de los lazos de confianza, de cooperación, de solidaridad, inclinando la balanza de las relaciones sociales hacia un individualismo aislacionista que se vivía como instancia de refugio y protección. Aislarse fue tanto un resultado buscado por la dictadura (ese cambio de mentalidad del que hablaba Martínez de Hoz) como una respuesta defensiva ante un panorama que restringía enormemente las posibilidades de la acción. Con notable claridad en este aspecto, Rodolfo Walsh instaba a luchar contra el terror rompiendo el aislamiento. $^{52}$ Pero hacerlo no sólo requería afrontar el miedo, sino además saberlo conscientemente (exigía mirar "a las espaldas"), y contar con alguien. ${ }^{53}$ Pero los otros se habían transformado en potenciales vigilantes.

En una imagen de la publicidad oficial del régimen, un soldado se acerca a la ventanilla del auto dirigiéndose a su conductor (que ocuparía el lugar de la toma fotográfica, es decir, de quien mira la publicidad). La leyenda que acompaña la fotografía redobla la mirada del soldado al interpelar al espectador bajo la forma escrituraria del diálogo: “-Documentos, por favor...”. Para luego continuar en un tono que nunca abandona la amenaza y que apela a las palabras propias de la nueva tecnología represiva: "Estamos de su lado. La violencia existe todavía en el país y el objetivo suyo y nuestro es lograr que desaparezca de una vez. Si usted es gente de paz participe comprometiéndose. Proteger es querer". La composición entre texto e imagen despliega múltiples significaciones, pero todas ellas tienden a generar y/o reforzar ciertas figuras de subjetividad.

\footnotetext{
51 Por supuesto, también pueden naufragar estos documentos cuando los universos nocionales y sistemas de pensamiento que los estudian los reducen a título ilustrativo o minimizan el poder cognitivo de la imagen por su conversión a lo legible. La historiografía en general tiene una enorme vacancia en el tratamiento de las imágenes, a pesar de su proliferación entre la documentación histórica. Tal vez esa constante pueda dejarse atrás gracias a ciertas obras de referencia que ahora circulan más ampliamente y a iniciativas recientes que alimentan esa expectativa; mencionemos como ejemplo, al respecto, la compilación de Feld, Claudia y Stites-Mor, Jessica, El pasado que miramos. Memoria e imagen ante la bistoria reciente, Buenos Aires, Paidós, 2009.

${ }^{52}$ Como se alentaba en los cables de ANCLA (Agencia de Noticias Clandestina): "Reproduzca esta información, hágala circular por los medios a su alcance: a mano, a máquina, a mimeógrafo, oralmente. Mande copias a sus amigos: nueve de cada diez las estarán esperando. Millones quieren ser informados. El terror se basa en la incomunicación. Rompa el aislamiento. Vuelva a sentir la satisfacción moral de un acto de libertad. Derrote el terror. Haga circular esta información"; en línea: en www.elortiba.org/ancla.html\#Las_cartas_y_la_cadena_informativa [consulta: marzo 2012].

53 No casualmente, “juntas podemos" es la frase que se repite en los relatos testimoniales de las primeras reuniones de aquellas mujeres que formarían Madres de Plaza de Mayo.
} 


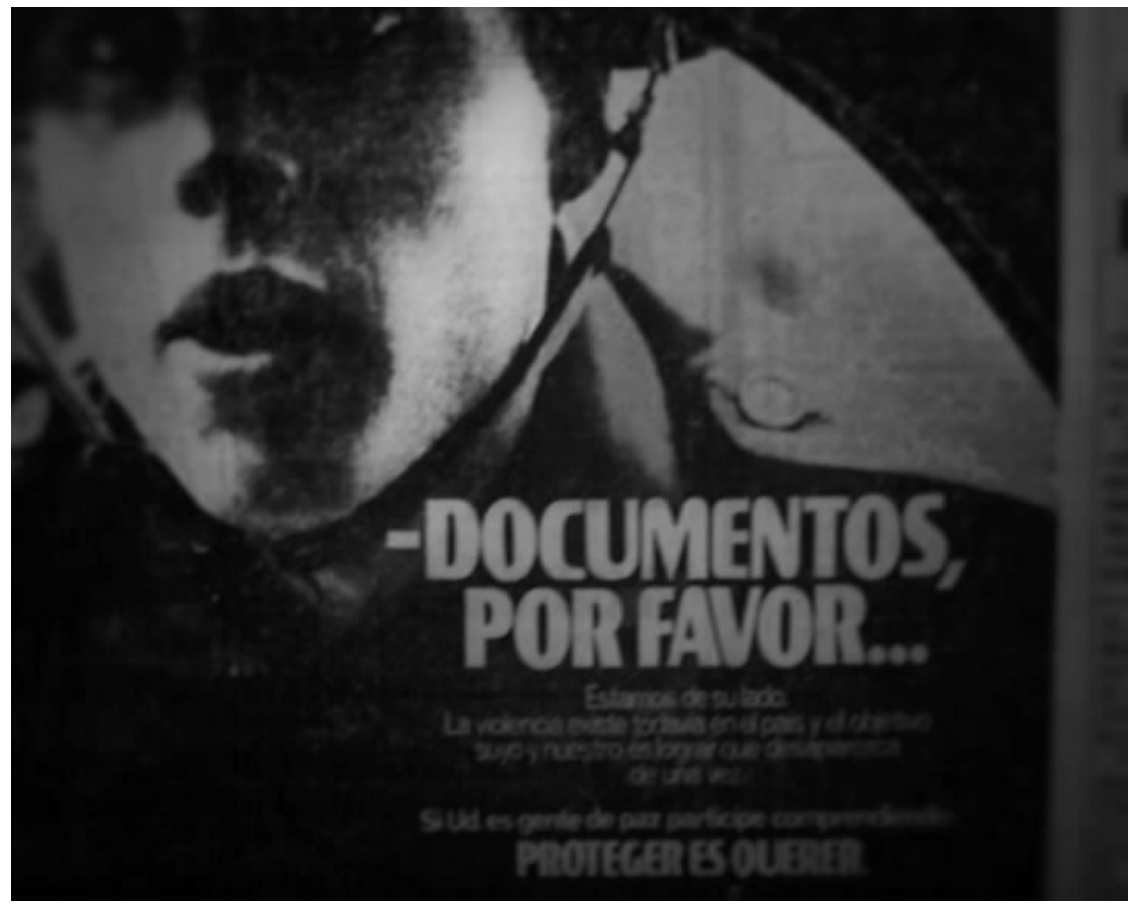

El requerimiento (“-Documentos, por favor...”) se convierte, visual y textualmente, en una exigencia, en una intim(id)ación. Lo que se pide es "una prueba de identidad", que no refiere al nombre propio de la documentación exigida sino a una toma de posición (política): "estamos de su lado", señala la publicidad, apremiando la definición del bando (es decir, del poder) en el que se tiene que ubicar el destinatario del mensaje. Mientras el "por favor" redobla la coacción de la orden, es la producción de una identificación con el poder militar lo que se exige; en otras palabras, un vuelco subjetivo hacia una identidad (una mismidad) con la violencia terrorista del Estado. A la par, la figura del soldado parece introducirse en el vehículo desde donde se realiza la fotografía y en el cual se compone el lugar del destinatario: se trata, así, de una intervención sobre el espacio privado (y aún íntimo) por medio de la orden de identidad; hay que identificarse con ese orden. ${ }^{54}$ Una orden de identidad que exige el compromiso y la complicidad con el terror ("participe comprometiéndose", prescribe el texto propagandístico).

Gesto invasivo del soldado en el lugar propio del ciudadano: el recorte de la imagen construye una relación asimétrica entre la figura militar y la del espectador/ocupante del vehículo. No sólo porque el soldado aparece situado por encima del punto de vista del destinatario, sino porque lo que queda fuera del campo fotográfico (la parte superior de la figura del soldado) construye una imagen en la que la fuerza militar ya ha penetrado en el campo de la visión propia de quien mira, ya se ha infiltrado en ese espacio propio del espectador.

Complementariamente, el rostro del soldado también ofrece una instancia de identificación que supone no la fuerza sino la inocencia. Sus rasgos aniñados ofician de tal símbolo para que el sujeto interpelado se refugie en esa representación como si fuera propia; es la posible respuesta a la conminación de una toma de posición de identidad: asumir ese semblante como espejo de una exposición de inocencia. Ese soldado podía ser cualquiera de los interpelados por la propaganda dictatorial, porque de hecho podía ser cualquier conscripto, cerrando el círculo representativo.

${ }^{54}$ Elizabeth Jelin señaló que una de las dimensiones del terror es el borramiento de las fronteras entre lo público y lo privado, es decir, de la capacidad del poder estatal de penetrar violentamente en espacios supuestamente preservados a su intromisión; cf. Jelin, Elizabeth, “A veinte años del planteo de una 'cultura del miedo'...”, op. cit. 
Pero ese otro que es uno y que aparenta inocencia y amabilidad es a la vez el lugar de la amenaza: se trata de un soldado, testimonio simbólico y también efectivo de la violencia estatal (como se dice en la jerga militar: "es un efectivo de la fuerza"). Cualquiera es, entonces y a la vez, el lugar de la mirada que vigila, que interpela por la identidad: ¿quién sos? ¿qué sos? ¿de qué lado estás? Rupturas de las confianzas, (casi) no quedan otros en quien confiar: aislarse, quedarse a-solas, asolado, es correlativo de una identificación (una posición de identidad) con una violencia de Estado generalizada que no admite otro bando.

Que esto es así también está anunciado en el mensaje propagandístico. "Si usted es gente de paz..." es una frase que admite la potencial disidencia y coloca al sujeto ante la necesidad de mostrar que lo es. Por ello la "violencia que todavía existe" no es identificada; se la nombra sólo como tal. Lo que posibilita al menos dos lecturas: que esa violencia es la que se muestra en la imagen; que esa violencia es cualquier apartamiento del mandato identitario por parte del destinatario del mensaje.

Esta última lectura es consistente con el desplazamiento de la figura del enemigo hacia la ubicua denominación de subversivo. Marina Franco ha expuesto este desplazamiento en los años que van de 1973 a $1976 .{ }^{55}$ De todos modos, la denominación es anterior. ${ }^{56}$ Como señaló Jorge Cernadas, ${ }^{57}$ mientras la revista Siete Días Ilustrados titulaba "El desafío cordobés" a su edición extra de 1969 sobre el Cordobazo - con el fondo de una fotografía que, abarcando tapa y contratapa, retrataba a la policía montada cordobesa en plena huída- el diario La Nación rezaba en su edición del 30 de mayo: "Graves hechos subversivos registráronse durante la jornada de ayer en Córdoba". Bien podrían leerse ambos titulares como partes de un mismo sintagma político, en el que el desafio es el "grave hecho subversivo". Este "desafío subversivo" no remitía a la violencia guerrillera sino a una potencia de trastrocamiento del orden social que el Cordobazo expresó como exceso de la convocatoria originaria. Ese "excedente político", que por un momento retiró de la escena a la violencia legal (como captaba la fotografía de tapa de Siete Días Ilustrados) parecía venir de la nada y, sin proponérselo expresamente, modificó la situación. ${ }^{58}$

Ese exceso, ese desborde, esa emergencia (en sus dos acepciones) que subvertía la situación, como lo demostraban el Cordobazo y otras puebladas, radicaba potencialmente en cualquiera y se debía a la movilización (politización) de cualquiera. Como lo indicaba con precisión un editorial de La Nación de 1975:

"La subversión que enfrenta la República no es sólo la «guerrilla», es esta apenas la metralleta de un fenómeno que ha calado hondo en la vida política, social y económica

\footnotetext{
${ }^{55}$ Franco, Marina, Un enemigo para la nación..., op. cit.

56 El término aparece incluso en la Ley de Residencia de 1902 en relación a las potenciales actitudes y comportamientos del activismo obrero.

57 Comunicación personal.

${ }^{58}$ Un exceso que se siguió manifestando en los años siguientes en la movilización de base, en la proliferación de distintas instancias de auto-organización de masas, y en eventos que excedían las manifestaciones encuadradas, desde las puebladas a las tomas que siguieron al 25 de mayo de 1973, para mencionar algunos de los ejemplos más importantes. Cf. Ramírez, Ana Julia, "Las puebladas en la Argentina de los '70. El Caso de General Roca, julio de 1972", ponencia presentada en LASA, Washington, septiembre 2001; Ramírez, Ana Julia, "La protesta popular en la Argentina, 1969-1973: el caso de la provincia de Tucumán”, ponencia presentada en el XXVII LASA Internacional Congress, Montreal, Canadá, 5 al 9 de septiembre de 2007; Ramírez, Ana Julia, "Las mediaciones locales de la protesta. El caso del trelewazo de octubre 1972", en Sociobistórica, Cuadernos del CISH, no 19/20, FaHCEUNLP/Prometeo, julio 2008; Abbattista, María Lucía y Ramírez, Ana Julia (2011), "Las tomas en la ciudad de La Plata. Aportes al estudio de la dinámica política durante el gobierno de Héctor Cámpora”, ponencia presentada en las XIII Jornadas Interescuelas/Departamentos de Historia, UNC, San Fernando del Valle de Catamarca, 10 al 13 de agosto de 2011.
} 
(...) esa subversión también se manifiesta en la fractura de ciertos valores mínimos de jerarquías y disciplina.... ${ }^{, 59}$

Subversivo se transformó en el significante que calificaba esa potencia de transformación del orden, capaz de nombrar, más allá de las identidades políticas partidarias, cada acto que produjera esa "fractura de los valores mínimos de jerarquía y disciplina", actos que expresaban que algo había "calado hondo", reformulando subjetividades y tramas sociales. El significante "subversivo" no designó sólo a aquellos que pretendían explícitamente cambiar el orden, invertirlo (o darlo vuelta, tal cual su etimología), sino a todo aquel que podía portar de modo latente otra versión, otra narración, y por lo tanto, potencialmente, otras jerarquías, o más radicalmente, ninguna jerarquía. La interpelación de la violencia estatal de la dictadura se dirigió, entonces, a cualquiera, y por ende, a todos, para que esa potencia subversiva de los sujetos fuera reprimida, suprimida, desaparecida. Tal como lo enuncia con claridad el mismo mensaje propagandístico "-Documentos, por favor", donde la palabra sobre la desaparición es expuesta para que se viera, aunque no se supiera. ${ }^{60}$

\section{Bibliografía}

Abbattista, María Lucía y Ramírez, Ana Julia, "Las tomas en la ciudad de La Plata. Aportes al estudio de la dinámica política durante el gobierno de Héctor Cámpora", ponencia presentada en las XIII Jornadas Interescuelas/Departamentos de Historia, UNC, San Fernando del Valle de Catamarca, 10 al 13 de agosto, 2011.

Actis, Munú; Aldini, Cristina; Gardella, Liliana; Lewin, Miriam y Tokar, Elisa, Ese infierno. Conversaciones de cinco mujeres sobrevivientes de la ESMA, Buenos Aires, Sudamericana, 2001.

Águila, Gabriela, "La dictadura militar argentina: interpretaciones, problemas, debates", en páginas. revista digital de la escuela de historia, año 1, n 1, Rosario, Facultad de Humanidades y Artes - UNR, 2008.

Berger, John, Mirar, Buenos Aires, de la Flor, 1998.

Butler, Judith, Marcos de guerra. Las vidas lloradas, Buenos Aires, Paidós, 2009.

Calveiro, Pilar, Poder y desaparición. Los campos de concentración en Argentina, Buenos Aires, Colihue, 1998.

Cohen, Stanley, Estados de negación. Ensayo sobre atrocidades y sufrimiento, Buenos Aires, British Council Argentina/Departamento de Publicaciones Facultad de Derecho UBA, 2005.

Corradi, Juan (1982-1983): "The Mode of Destruction: Terror in Argentina." Telos. A Quarterly Journal of Critical Thought, $\mathrm{n}^{\circ}$ 54, invierno, pp. 61-76, 1982-83.

de Santos, Blas, La fidelidad del olvido. Notas para el psicoanálisis de la subjetividad militante, Buenos Aires, El Cielo por Asalto, 2006.

Didi-Huberman, Georges, Imágenes pese a todo. Memoria visual del Holocausto, Barcelona, Paidós, 2004.

Dussell, Inés, Finocchio, Silvia y Gojman, Silvia, Haciendo memoria en el país del nunca más, Buenos Aires, EUDEBA, 1997.

\footnotetext{
59 .- La Nación, 7 de octubre de 1975, cit. en Franco, Marina, Un enemigo para la nación..., op. cit. p. 250.

${ }^{60}$.- Por todo lo expuesto, que el dispositivo del terror estatal estuviera dirigido hacia cualquiera no contradice —más bien refuerza - la focalización del aparato de detención y desaparición de personas en la militancia política y sindical combativa. Cf. el señalamiento de O’Donnell respecto de la acentuación del pathos autoritario en la familia pues muchos padres "sintieron que «retomando el mando» para garantizar la despolitización de sus hijos los salvarían del destino de tantos otros jóvenes"; O’Donnell, cit., p. 16.
} 
Feld, Claudia y Stites-Mor, Jessica (comps.), El pasado que miramos. Memoria e imagen ante la bistoria reciente, Buenos Aires, Paidós, 2009.

Franco, Marina, Un enemigo para la nación. Orden interno, violencia y "subversión", Buenos Aires, Fondo de Cultura Económica, 2012.

Gamarnik, Cora, "Imágenes de la dictadura militar. La fotografía de prensa antes, durante y después del golpe de Estado de 1978 en Argentina", en Pérez Fernández, Silvia y Gamarnik, Cora, "Artículos de investigación sobre fotografía", Montevideo, CMDF, 2011, pp. 49-80.

Gusmán, Luis, Villa, Buenos Aires, Edhasa, 1996.

Jelin, Elizabeth, “A veinte años del planteo de una 'cultura del miedo' ¿son los mismos miedos? Notas (muy preliminares e incompletas) para una discusión”, en AA.VV., Miedos y memorias en las sociedades contemporáneas, Documentos de trabajo del Seminario de trabajo, Córdoba, UNC/Núcleo Memoria IDES/ComunicArte, 2006, pp. 57-63.

Jelin, Elizabeth y Kaufman, Susana, "Los niveles de la memoria: reconstrucciones del pasado dictatorial argentino", en Entrepasados. Revista de historia, año X, n 20/21, Buenos Aires, 2001, pp.9-34.

Jinkis, Jorge, Violencias de la memoria, Buenos Aires, Edhasa, 2011.

Kaufman, Susana, "Miedo. Perspectivas subjetivas y lazo social", en AA.VV., Miedos y memorias en las sociedades contemporáneas, Documentos de trabajo del Seminario de trabajo, Córdoba, UNC/Núcleo Memoria IDES/ComunicArte, 2006, pp. 181-188.

Levín, Florencia, "Arqueología de la memoria. Algunas reflexiones a propósito de Los vecinos del horror. Los otros testigos", en Entrepasados. Revista de historia, año XIV, n 28, Buenos Aires, 2005, pp. 47-63.

O’Donnell, Guillermo, "Democracia en la Argentina: micro y macro", en Oscar Oszlak (comp.), "Proceso", crisis y transición democrática, tomo I, Buenos Aires, Centro Editor de América Latina, 1984.

Pittaluga, Roberto, "La memoria según Trelew", en Sociohistórica. Cuadernos del CISH, no 19/20, UNLP, La Plata, 2008, pp. 81-111.

Pittaluga, Roberto, "El pasado reciente argentino: interrogaciones en torno a dos problemáticas", en Bohoslavsky, E.; Franco, M., Iglesias, M y Lvovich, D., Problemas de historia reciente del Cono sur, Buenos Aires, UNGS/Prometeo Libros, 2010, pp. 23-35.

Ramírez, Ana Julia, "Las puebladas en la Argentina de los '70. El Caso de General Roca, julio de 1972", ponencia presentada en LASA, Washington, septiembre, 2001.

Ramírez, Ana Julia, "La protesta popular en la Argentina, 1969-1973: el caso de la provincia de Tucumán", ponencia presentada en el XXVII LASA Internacional Congress, Montreal, Canadá, 5 al 9 de septiembre, 2007.

Ramírez, Ana Julia, "Las mediaciones locales de la protesta. El caso del trelewazo de octubre 1972", en Sociohistórica, Cuadernos del CISH, n 19/20, FaHCE-UNLP/Prometeo, julio, 2008.

Sartre, Jean-Paul, Lo imaginario. Psicología fenomenológica de la imaginación, Buenos Aires, IberoAmericana, 1948 [1940].

Sartre, Jean-Paul, La imaginación, Madrid, Sarpe, 1984 [1936].

Scavino, Dardo, La era de la desolación. Ética y moral en la Argentina de fin de siglo, Buenos Aires, Manantial, 1999.

Schindel, Estela, Desaparición y sociedad: una lectura de la prensa gráfica argentina (1975-1978), Berlín, Freien Universität Berlín, 2003.

Schmucler, Héctor, "Usos políticos del miedo", en AA.VV., Miedos y memorias en las sociedades contemporáneas, Documentos de trabajo del Seminario de trabajo, Córdoba, UNC/Núcleo Memoria IDES/ComunicArte, 2006, pp. 287-297.

Sontag, Susan, Sobre la fotografía, Buenos Aires, Alfaguara, 2007

Vitale, María Alejandra (s/f.), "Memoria y acontecimiento. La prensa escrita ante el golpe militar de 1976". En: http://historiapolitica.com/datos/biblioteca/vitale.pdf [última consulta: mayo 2012] 